Romuald Grzybowski

(Gdańsk)

\title{
Pięćdziesięciolecie gdańskiej historii wychowania ${ }^{1}$
}

\section{Warunki rozwoju historii wychowania w środowisku gdańskim po 1945 roku. Okoliczności powstania Zakładu Historii Nauki, Oswiaty i Wychowania}

Rozwój historii wychowania w Gdańsku wiąże się ściśle z początkami i rozwojem nauk pedagogicznych $\mathrm{w}$ tym mieście po roku 1945. Powrót Gdańska wraz z całym Pomorzem Nadwiślańskim oraz innymi terenami zaliczanymi do tzw. Ziem Odzyskanych ${ }^{2}$ do Macierzy, otworzył bowiem nowy rozdział w jego dziejach. Dotyczy to także możliwości i kierunków rozwoju m.in. pedagogiki i związanej z nią historii wychowania.

Należy przypomnieć, że Gdańsk, mimo wielowiekowych tradycji naukowych ${ }^{3}$, w chwili zakończenia II wojny światowej, nie mógł poszczycić się znaczącym dorobkiem w dziedzinie nauk o wychowaniu ${ }^{4}$. Jak zauważa prof. Klemens Trzebiatowski, w wiekach wcześniejszych (XVI-XVIII) rozwijały się tu nauki związane raczej z potrzebami ekonomicznymi miasta oraz ze specyficzną drogą rozwoju historycznego Gdańska i Pomorza Nadwiślańskiego. Prace o charakterze pedagogicznym stanowiły mniej znaczącą część dorobku naukowego uczonych gdańskich. Natomiast w okresie międzywojennym nauka polska nie znajdowała w Wolnym Mieście Gdańsku właściwych warunków do rozwojus.

\footnotetext{
${ }^{1}$ Prezentowany tekst, z pewnym wyprzedzeniem, przybliża dzieje i dorobek Zakładu Historii Nauki, Oświaty i Wychowania Uniwersytetu Gdańskiego. Okazją ku temu jest przypadająca w 2009 r. pięćdziesiąta rocznica jego powołania: rozpoczął on bowiem działalność - jako Katedra Historii Oświaty i Wychowania Wyższej Szkoły Pedagogicznej w Gdańsku - 1 października 1959 roku. Por.: Działalność naukowa Wyższej Szkoły Pedagogicznej w Gdańsku w latach 1958-1959, Biuletyn nr 1 WSP w Gdańsku, Gdańsk 1960, s. 7.

${ }^{2}$ Nazywanych też bardziej precyzyjnie Ziemiami Zachodnimi i Północnymi.

${ }^{3}$ Por. m.in.: K. Kubik, L. Mokrzecki, Trzy wieki nauki gdańskiej, Wrocław 1976; M. Andrzejewski, L. Mokrzecki, J. A. Włodarski, Zarys dziejów Uniwersytetu Gdańskiego, Gdańsk 2006, s. 9-24.

${ }^{4}$ Prof. Lech Mokrzecki wskazuje jednak, że uczeni gdańscy już w XVIII w. podejmowali badania nad przeszłością gdańskiego szkolnictwa. Podobne zjawisko dostrzega też w drugiej połowie XIX i początkach XX w. Por. L. Mokrzecki, Współczesne kierunki badań nad dziejami oświaty i nauki w środowisku gdańskim $i$ ich najnowsze wyniki, w: Historia wychowania w XX wieku. Dorobek i perspektywy, pod red. T. Gumuły, J. Krasuckiego, S. Majewskiego, Kielce 1998, s. 515.

${ }^{5}$ K. Trzebiatowski, Glówne kierunki prac naukowo-badawczych Instytutu Pedagogiki i Psychologii Uniwersytetu Gdańskiego, „Zeszyty Naukowe Wydziału Humanistycznego Uniwersytetu Gdańskiego, Pedagogika, Psychologia, Historia Wychowania" 1973, nr 2, s. 129.
} 
Działające tu, począwszy od 1922 r., Towarzystwo Przyjaciół Nauki i Sztuki podejmowało głównie działania zmierzające do umacniania polskości na tym terenie drogą ukazywania powiązań historycznych, kulturalnych Gdańska i Pomorza Nadwiślańskiego (Prus Królewskich, funkcjonujących w okresie zaborów jako Prusy Zachodnie), z innymi ziemiami polskimi ${ }^{6}$. Godne odnotowania jest także powstanie w 1922 r. Gimnazjum Polskiego Macierzy Szkolnej w Gdańskư ${ }^{7}$ dysponującego dobrze wykształconą, oddaną kadrą pedagogiczna, która po zakończeniu II wojny światowej zasiliła powstające masowo polskie szkoły średnie oraz zakłady kształcenia nauczycieli w Gdańsku.

Należy też pamiętać, że Gdańsk - mimo licznych prób podejmowanych na przestrzeni wieków - w roku 1945 nadal nie dysponował własnym uniwersytetem ${ }^{9}$. W rezultacie, nauki pedagogiczne zyskały należne warunki rozwoju dopiero $w$ murach utworzonej w 1946 r. Państwowej Wyższej Szkoły Pedagogicznej ${ }^{10}$. Do roku 1954 placówka ta należała do kategorii wyższych szkół zawodowych nieakademickich o trzyletnim okresie kształcenia ${ }^{11}$. Celem PWSP (od 1952 r. Wyższej Szkoły Pedagogicznej) w Gdańsku, było kształcenie nauczycieli - początkowo dla starszych klas szkół powszechnych, a od 1 czerwca 1949 r. nauczycieli przedmiotów ogólnokształcących dla szkół średnich ${ }^{12}$.

Dla właściwego rozwoju gdańskiej historii wychowania decydujące znaczenie miał zatem charakter i zadania wyższych szkół pedagogicznych. Proces ich dostosowywania do potrzeb systemu oświatowego w PRL oraz złożonych oczekiwań ideologicznych i politycznych, kierowanych pod adresem szkolnictwa średniego i wyższego przez rządzących krajem komunistów, był długi ${ }^{13}$. Rzutowało to na ograniczone w pierwszych latach moźliwości rozwoju nauki w tych placówkach, które ani nie dysponowały kadrą

${ }^{6}$ Zostało ono założone 11 lipca 1922 r. przez 50 przedstawicieli inteligencji polskiej w Gdańsku z ks. prof. dr Kamilem Kantakiem na czele, jako polskie towarzystwo naukowe pod nazwą: Towarzystwo Przyjaciół Nauki i Sztuki w Gdańsku. Por. M. Pelczar, Zarys dziejów Gdańskiego Towarzystwa Naukowego 1922-1971, w: 50 lat Gdańskiego Towarzystwa Naukowego. 1922-1972. Ksiegga Pamiatkowa, Gdańsk 1972, s. 11. Por. także: Siedemdziesiąt pięć lat Gdańskiego Towarzystwa Naukowego. 1922-1997. Księga Pamiqtkowa, pod red. Marka Latoszka, Gdańsk 1998.

${ }^{7}$ Pierwotnie szkoła nosiła nazwę Gimnazjum Polskie w Gdańsku. W 1934 r. zmieniono ją na Gimnazjum Macierzy Szkolnej w Gdańsku, natomiast od roku 1935/36 oficjalna nazwa szkoły brzmiała Gimnazjum im. Józefa Piłsudskiego Macierzy Szkolnej w Gdańsku. Por. Z. Rynduch, W 50-lecie powstania Gimnazjum Polskiego w Gdańsku, „Rocznik Gdański” 1971, t. 31, z. 2, s. 192.

${ }^{8}$ Wśród zashużonych nauczycieli Gimnazjum Polskiego w Gdańsku wymienić należy takich pedagogów (w tym wielu późniejszych uczonych), jak: Jan Augustyński, Bernard Janik, Michał Urbanek, Barbara Mielcarzewicz, Eustachy Tarnawski, Marcin Dragan, Edwina Jędykiewicz, Zbigniew Rynduch, Józef Welniak, Jan Trzciniecki, Janina Ślęczka, Helena Rakowska i inni. Por. Gimnazjum Polskie Macierzy Szkolnej w Gdańsku 1922-1939. Księga Pamiq̨tkowa w Sześćdziesięciopięciolecie Zalożenia Gimnazjum, cz. II, pod red. K. Sroczyńskiej-Wyczańskiej, Wrocław-Warszawa-Kraków-Gdańsk Łódź 1989, s. 303-320.

${ }^{9}$ R. Grzybowski, Uniwersytet Gdański, w: Encyklopedia pedagogiczna XXI wieku, t. VI, Warszawa 2007, s. $991-996$.

${ }^{10}$ Zarządzenie ministra oświaty z dnia 24 września 1946 roku. W tym czasie powołano do życia także PWSP w Krakowie, Łodzi i Katowicach, Dz. Urz. Min. Ośw. 1946, nr 11, poz. 376.

${ }^{11}$ R. Grzybowski, Okoliczności powstania Wyższej Szkoły Pedagogicznej w Gdańsku i rozwój jej infrastruktury w latach 1946-1949, „Rocznik Gdański” t. LVIII, 1988, z. 1, s 79-94.

${ }^{12}$ Zarządzenie ministra oświaty z 28 czerwca 1949 roku w sprawie uprawnień absolwentów wyższych szkół pedagogicznych i Instytutów Pedagogicznych ZNP, Dz. Urz. Min. Ośw. 1949, nr 10, poz. 182.

${ }^{13}$ Por. R. Grzybowski, Wyższe szkohy pedagogiczne w Polsce w latach 1946-1956, Gdańsk 2000, s. 54-72. 
zdolną do podejmowania działalności naukowej, ani nie wykształciły struktur organizacyjnych, właściwych dla szkół wyższych. Mimo że po 1949 roku w sferze kształcenia nauczycieli szkół średnich wyższe szkoły pedagogiczne spełniały te same zadania co uniwersytety, aż do 1954 r. nie były one w stanie realizować funkcji naukowo-badawczej.

Impas, w którym znalazły się omawiane placówki w pierwszych latach swego istnienia przełamały dopiero kolejne decyzje Ministerstwa Oświaty: o utworzeniu w nich wydziałów i katedr (z grudnia 1952 r.) ${ }^{14}$; o nadaniu im odrębnych statutów (z grudnia 1953 r.) ${ }^{15}$; o przedłużeniu w nich nauki do lat 4 i nadaniu uprawnień ich absolwentom do ubiegania się o tytuł magistra w zakresie obranej specjalności ${ }^{16}$. Udoskonalona struktura organizacyjna oraz przedłużenie okresu studiów w wyższych szkołach pedagogicznych, kończących się egzaminem magisterskim stworzyło właściwe warunki do rozwoju działalności naukowej. Odnosi się to także do rozwoju nauk pedagogicznych, choć podkreślić należy, że w pierwszych kilkunastu latach istnienia wyższych szkół pedagogicznych pedagogika $\mathrm{i}$ związana $\mathrm{z}$ nią historia wychowania spełniały funkcję pomocniczą w procesie kształcenia nauczycieli - specjalistów przedmiotowych. Natomiast historia wychowania jako przedmiot kształcenia obecna była już w pierwszym planie studiów państwowych wyższych szkół pedagogicznych. Jego autorzy przewidzieli na realizację treści nauczania z zakresu historii wychowania 3 godziny na trzecim roku studiów ${ }^{17}$.

W wymiarze organizacyjnym historia wychowania, podobnie jak pedagogika, funkcjonowała w obrębie wydziału Filologiczno-Historycznego. Rozwijała się tu w ramach utworzonej w 1953 roku Katedry Pedagogiki, która - obok zakładu pedagogiki - prowadziła zakład psychologii i zakład historii wychowania ${ }^{18}$. Sama pedagogika zaś do połowy lat pięćdziesiątych spostrzegana była jako przedmiot natury ideologicznej, służący ideowemu i politycznemu urabianiu (indoktrynacji) osobowości przyszłych nauczycieli szkół średnich $^{19}$. Założenie to rzutowało negatywnie zarówno na nauczanie pedagogiki i histo-

\footnotetext{
${ }^{14}$ Zarządzenie ministra oświaty z 13 grudnia 1952 roku w sprawie utworzenia wydziałów i katedr w wyższych szkołach pedagogicznych, Dz. Urz. Min. Ośw. 1952, nr 21, poz. 197.

${ }^{15}$ Zarządzenie ministra oświaty z 14 grudnie 1953 roku w sprawie nadania statutu Wyższej Szkole Pedagogicznej w Gdańsku, Dz. Urz. Min. Ośw. 1954,, nr 1, poz. 1 .

${ }^{16}$ Zarzadzenie ministra oświaty z 14 czerwca 1954 roku w sprawie ustalenia czasu trwania studiów w wyższych szkołach pedagogicznych i wydziałach zaocznych tych szkót, Dz. Urz. Min. Ośw. 1954, nr 10, poz. 79.

${ }^{17} \mathrm{~W}$ tym samym planie studiów na nauczanie pedagogiki i dydaktyki ogólnej, występujących jako jeden przedmiot, przewidywano 5 godzin na drugim roku studiów. Por. Plan godzin i wytyczne programu nauki w Państwowej Wyższej Szkole Pedagogicznej (załącznik do statutu Państwowych wyższych szkół pedagogicznych). Zarządzenie ministra oświaty $\mathrm{z}$ dnia 12 marca 1946 roku $\mathrm{w}$ sprawie statutu państwowych Wyższych Szkół Pedagogicznych, Dz. Urz. Min. Ośw. 1946, nr 2, poz. 47.

${ }^{18}$ Uznajemy jednak, że właściwy rozwój historii wychowania nastąpił wraz z jej wyodrębnieniem się ze struktur Katedry Pedagogiki. Z dniem 1 X 1959 r. Katedra Historii Oświaty i Wychowania uzyskała status autonomicznej jednostki Wydziału Humanistycznego WSP. Por.: Dzialalność naukowa Wyższej Szkoły Pedagogicznej w Gdańsku w latach 1958-1959, Biuletyn nr 1 WSP w Gdańsku, Gdańsk 1960, s. 7. Katedrą Pedagogiki kierowała w tym czasie doc. dr Romana Miller.

${ }^{19}$ Wyższe szkoły pedagogiczne miały bowiem zająć się przygotowaniem ,nauczycieli nowego typu", to znaczy nauczycieli „zdolnych do czynnego udziału w budowie zrębów socjalizmu w Polsce na odcinku oświaty i kultury". Por. Instrukcja Ministerstwa Oświaty z dnia 13 października 1949 roku w sprawie organizacji roku szkolnego w Państwowych Wyższych Szkołach Pedagogicznych, Dz. Urz. Min. Ośw. 1949, nr 16, poz. 273.
} 
rii wychowania, jak i na badania naukowe podejmowane w obrębie omawianych dyscyplin naukowych.

Do wyodrębnienia się historii wychowania z nauk pedagogicznych w Gdańsku przyczyniła się decyzja Ministerstwa Oświaty o uruchomieniu w WSP w Gdańsku kierunku „pedagogika”. Zabiegi kierownictwa uczelni o uruchomienie w Gdańsku studiów pedagogicznych trwały od kwietnia 1957 r. Nowy kierunek utworzono ostatecznie 1 października $1958 \mathrm{r}^{20} \mathrm{~W}$ pierwszym okresie pedagogika była ona prowadzona tylko na studiach wieczorowych, w obrębie Studium dla Pracujących, później także na studiach zaocznych i stacjonarnych. Utworzenie pedagogiki jako kierunku studiów doprowadziło do wielu zmian w strukturze Wydziału Filologiczno-Historycznego, w tym m.in. do powołania $\mathrm{z}$ dniem 1 lipca $1958 \mathrm{r}$. sekcji pedagogiki ${ }^{21}$. Właśnie w jej ramach zaczęto tworzyć nowe katedry, zajmujące się kształceniem studentów pedagogiki oraz podejmujące badania naukowe $\mathrm{z}$ zakresu nauk o wychowaniu ${ }^{22}$.

Pierwszą spośród nowych katedr pedagogicznych powołano, z dniem 1 października 1959 r., Katedrę Historii Oświaty i Wychowania ${ }^{23}$. Została ona utworzona na bazie dorobku naukowego ówczesnego docenta dr Kazimierza Kubika oraz jego współpracowników. W 1969 r. Katedra Historii Oświaty i Wychowania, podobnie jak inne katedry w całym szkolnictwie wyższym w Polsce, przemianowana została na Zakład Historii Oświaty i Wychowania i włączona w struktury utworzonego $\mathrm{z}$ dniem 1 października $1969 \mathrm{r}$. Instytutu Pedagogiki i Psychologii WSP (od 1970 r. Uniwersytetu Gdańskiego) ${ }^{24}$. Począwszy od 1975 roku Zakład wchodził w skład Instytutu Pedagogiki UG, przy czym został później przemianowany na Zakład Historii Nauki, Oświaty i Wychowania. Pod taką nazwą funkcjonuje do dzisiaj.

\section{Glównie nurty badań gdańskich historyków wychowania}

Bliskość organizacyjna historii oświaty i wychowania oraz pedagogiki sprawiła, że obie te dyscypliny naukowe rozwijały się w Gdańsku równolegle. Owocowało to na

\footnotetext{
${ }^{20}$ R. Grzybowski, Poczqtki oraz niektóre aspekty rozwoju nauk pedagogicznych w Gdańsku po 1945 roku, w: Gdańskie rodowody pedagogiczne. Geneza, kontynuacje, inspiracje, przeniesienia znaczeń wychowawczych, pod red. E. Rodziewicz, K. Rzedzieckiej, E. Zalewskiej, Gdańsk 2004, s. 115.

${ }^{21}$ Zarządzenie ministra oświaty $\mathrm{z}$ dnia 19 maja 1958 roku w sprawie zmian organizacyjnych w WSP w Gdańsku, Dz. Urz. Min. Ośw. 1958, nr 8, poz. 96.

${ }^{22}$ W roku 1957 powołano Katedrę Psychologii, a w roku 1958 Katedrę Socjologii.

${ }^{23}$ Archiwum Państwowe w Gdańsku, Materiały Wyższej Szkoły Pedagogicznej w Gdańsku [dalej: APG, WSP], uchwała Senatu WSP w Gdańsku w sprawie zawieszenia rekrutacji na kierunku pedagogika, sygn. 1317/21. Z dniem 1 października 1960 r. rozpoczęła działalność Katedra Dydaktyki (Zarz. ministra oswiaty z dnia 27 lipca 1960 roku, Dz. Urz. Min. Ośw. 1960, nr 11, poz. 195).

${ }^{24}$ Instytuty wprowadzono w całym szkolnictwie wyższym w Polsce na podstawie art. 11 po nowelizacji z 20 grudnia 1968 roku - art. 10 ustawy z dnia 5 listopada 1958 roku o szkolnictwie wyższym. Decyzja kierownictwa partii przywracająca skrajnie niedemokratyczne rozwiązania w szkolnictwie wyższym była, jak wiadomo, reakcją na tzw. wydarzenia marcowe 1968 r. Instytuty miały zapewnić partii pełniejszą kontrolę nad środowiskiem akademickim.
} 
przełomie lat 50. i 60. różnorodnymi inicjatywami naukowymi, w tym wspólną redakcją zeszytów naukowych ${ }^{25}$. Wcześniej wszakże pracownicy Katedry Historii Oświaty i Wychowania podjęli właściwe badania naukowe. Ich początek datuje się na pierwszą połowę lat pięćdziesiątych. Potwierdzeniem tego były wystąpienia Kazimierza Kubika i Klemensa Trzebiatowskiego na zorganizowanej w 1954 r. w Gdańsku sesji Polskiej Akademii Nauk w Gdańsku ${ }^{26}$. Właściwy rozwój badań z zakresu historii wychowania przypada na okres po 1956 r. Zaczęły wtedy ukazywać się nie tylko pojedyncze artykuły naukowe i recenzje, ale także prace zwarte. Kilkuletnie opóźnienie procesu rozwoju gdańskiej historii wychowania wynikało m.in. $\mathrm{z}$ prawie czteroletniej absencji K. Kubika w WSP, spowodowanej jego motywowanym względami politycznymi aresztowaniem $\mathrm{i}$ zwolnieniem z pracy w $1952 \mathrm{r}^{27}$ Zajęcia $\mathrm{z}$ historii wychowania prowadzili $\mathrm{w}$ tych latach zatrudnieni na stanowiskach zastępcy profesora mgr Bolesław Pieśniarski i mgr Klemens Trzebiatowski ${ }^{28}$.

W tym okresie zainteresowania naukowe pracowników Katedry Historii Oświaty i Wychowania koncentrowały się głównie wokół przeszłości naukowej i oświatowej Gdańska w okresie staropolskim, a zwłaszcza na dziejach i dorobku naukowym Gdańskiego Gimnazjum Akademickiego. Systematycznie rozwijał się też nurt badań skupionych na tradycjach nauczania historii w dawnej Rzeczypospolitej. Już w latach 60. XX w. gdańscy historycy wychowania wyraźnie zaznaczyli swą obecność w gronie badaczy podejmujących problematykę kształcenia i wychowania dzieci i młodzieży polskiej Pomorzu Gdańskim w okresie niewoli narodowej, a zwłaszcza w drugiej połowie XIX i w pierwszych latach XX w. Inicjowali także badania związane z najnowszymi dziejami oświaty i wychowania zarówno dzieci, młodzieży, jak i dorosłych, tak w ujęciu regionalnym, jak i ogólnopolskim. Znaczne osiągnięcia odnotowali zwłaszcza na polu badań nad dziejami wychowania i szkolnictwa morskiego ${ }^{29}$.

Profil badawczy pracowników Zakładu ustabilizował się w dekadzie lat 70. i 80 . XX w. Jednak dekada lat 90 . XX w. oraz początek XXI w. przyniosły wzbogacenie problematyki badawczej. Zadecydowały o tym nie tylko zmieniające się oczekiwania pedagogów, kierowane pod adresem historyków wychowania, lecz także wymiana pokoleniowa, dokonująca się w obrębie Zakładu. W tym okresie prace badawcze pracowników Zakładu koncentrowały się w obrębie trzech grup problemów. W obrębie pier-

\footnotetext{
${ }^{25}$ Od 1958 r. Wydział Humanistyczny WSP w Gdańsku wydawał „Gdańskie Zeszyty Humanistyczne”, a w 1970 r. zaczęły się ukazywać „Zeszyty Naukowe Wydziału Humanistycznego. Pedagogika, Historia Wychowania".

${ }^{26}$ K. Kubik, Polskie szkolnictwo prywatne w Gdańsku w XVI-XVIII wieku, w: Konferencja Pomorska Polskiej Akademii Nauk, Warszawa 1956; K. Trzebiatowski, Szkolnictwo i oświata polska na Ziemiach Pomorza Zachodniego w okresie międzywojennym 1918-1939, w: Konferencja Pomorska PAN, Warszawa 1956.

${ }^{27}$ Wątek ten wyjaśniam w dalszej części, omawiając postać i dorobek prof. K. Kubika.

${ }^{28}$ B. Pieśniarski na stałe związany był z Uniwersytetem Mikołaja Kopernika w Toruniu, gdzie byl zatrudniony w Katedrze Pedagogiki. Por. W. Szulakiewicz, Historia wychowania w Polsce 1944-1956, Kraków 2006 , s. 61 .

${ }^{29}$ Por.: L. Mokrzecki, Wspótczesne kierunki badan nad dziejami oświaty i nauki w środowisku gdańskim $i$ ich najnowsze wyniki, w: Historia wychowania w XX wieku. Dorobek i perspektywy, pod red. T. Gumuły, J. Krasuckiego, Kielce 1998, s. 515-525; idem: Historia wychowania w Gdańsku z perspektywy pięćdziesięciolecia (1946-1996), „,Ars Educandi” t. II, 2000, s. 19-33.
} 
wszego obszaru badań gdańscy historycy wychowania, przede wszystkim prof. L. Mokrzecki, dr K. Puchowski ${ }^{30}$ i dr J. Taraszkiewicz, prowadzili dociekania dotyczące dziejów edukacji historycznej w szkolnictwie europejskim do końca XVI w.; historiografii gdańskiej doby Odrodzenia i Baroku; edukacji historycznej w jezuickich kolegiach Rzeczypospolitej (1565-1773); historii szkolnictwa jezuickiego; nauczania historii w kolegiach pijarskich w Rzeczypospolitej do XVIII w.; ideałów i kierunków wychowania w szkolnictwie polskim XVI-XVIII w.; edukacji elit politycznych Rzeczypospolitej Obojga narodów, dziejów nauki i uczonych, szczególnie jezuitów i profesorów szkół protestanckich I Rzeczypospolitej; historii rozwoju różnych dyscyplin naukowych w Prusach Królewskich; dziejów dydaktyk niektórych dyscyplin. Po 2005 r. ten obszar badawczy wzbogaciły dociekania skupione na filozofii szkolnej w Gdańskim Gimnazjum Akademickim oraz problematyce nauczania filozofii w szkolnictwie gdańskim w okresie staropolskim $^{31}$.

Drugi zakres zagadnień, podejmowanych przez pracowników Zakładu, w tym głównie przez dr J. Szewsa - obecnie emerytowanego adiunkta Zakładu, dr L. Burzyńską-Wentland, dr T. Maliszewskiego oraz prof. UG, dr hab. R. Grzybowskiego, obejmował takie problemy badawcze, jak: nauczanie języka polskiego oraz tajne związki młodzieży polskiej, uczącej się w gimnazjach pruskich na terenie Prus Zachodnich w okresie niewoli narodowej, rola rodziny, prasy polskiej oraz organizacji społecznych w wychowaniu patriotycznym dzieci polskich w zaborze pruskim; strajki dzieci polskich w szkolnictwie ludowym w Prusach Zachodnich w pierwszych latach XX w.

W obrębie trzeciego obszaru badań przedmiotem dociekań podejmowanych przez prof. UG, dr hab. R. Grzybowskiego, dr L. Burzyńską-Wentland i dr J. Żerko były problemy obejmujące: przemiany ideałów wychowawczych na przestrzeni dziejów; kształcenie nauczycieli na poziomie średnim i półwyższym w Polsce w latach 1945-1989; kształcenie kadr kultury fizycznej w Polsce w XX w.; rozwój szkolnictwa wyższego w Polsce w latach 1945-1989; kształcenie nauczycieli w szkołach wyższych w Polsce po 1945 r., w tym zwłaszcza w wyższych szkołach pedagogicznych; szkołę jako przestrzeń ścierania się laickiej, partyjnej koncepcji wychowania oraz katolickiej i narodowej wizji edukacji narodu, lansowanej przez Kościół i rodzinę polską w latach 1945-1989; system zarządzania oświatą w Polsce na tle innych państw; kształcenie i dokształcanie nauczycieli w krajach Unii Europejskiej; rozwój myśli resocjalizacyjnej w Polsce do końca XX wieku; oświatę i szkolnictwo mniejszości narodowych i etnicznych w Polsce w okresie transformacji ustrojowej w Polsce w świetle uwarunkowań prawnych i społecznych po $1989 \mathbf{r}$.

Znaczącym obszarem badawczym stała się problematyka odnosząca się do edukacji pozaszkolnej i kształcenia dorosłych w Polsce oraz w innych krajach europejskich, w tym zwłaszcza w Szwecji. Stanowi ona domenę dr. T. Maliszewskiego, który podejmuje badania odnoszące się m.in. do historii polskich uniwersytetów ludowych; dawnej i najnowszej historii szwedzkiej oświaty dorosłych; historii myśli edukacyjnej i współpracy w dziedzinie oświaty dorosłych. W ostatnim okresie szczególnie dużo uwagi skupia na tematyce uniwer-

\footnotetext{
${ }^{30}$ W maju 2008 r. habilitował się na Wydziale Nauk Społecznych UG.

${ }^{31}$ Prowadzi je mgr Mariusz Brodnicki - doktorant prof. L. Mokrzeckiego, zatrudniony na stanowisku asystenta w Zakładzie Historii Nauki, Oświaty i Wychowania.
} 
sytetów ludowych w polskiej myśli i praktyce pedagogicznej. Dopełnieniem jego zainteresowań badawczych są najnowsze dzieje demokratyzacji oświaty w Polsce.

Po 2005 r. działalność badawcza Zakładu wzbogacona została dodatkowo o nowe problemy i zagadnienia, takie jak: hermeneutyczny model gdańskiego teatru szkolnego; wielokulturowość i wieloreligijność Gdańska; edukacja elit politycznych w Europie w czasach nowożytnych; edukacja pozaszkolna społeczeństwa polskiego Pomorza Nadwiślańskiego w okresie zaborów; dziecko i rodzina w różnych okresach dziejów społeczeństwa polskiego, w tym w stalinowskim modelu państwa totalitarnego (1945-1956); opieka nad dzieckiem w Polsce w latach 1918-1989 (koncepcje teoretyczne i rozwiązania systemowe); rozwój nauk pedagogicznych w Polsce po 1945 r. ze szczególnym uwzględnieniem Gdańska; dzieje pomocy społecznej i Caritas w Polsce po 1945 r.; opiekuńcza i wychowawcza działalność domów kultury w województwie gdańskim; rozwój szkół różnych szczebli w poszczególnych miastach i powiatach województwa gdańskiego. Badania w tym zakresie prowadzą m.in.: prof. UG, dr hab. K. Puchowski, prof. UG, dr hab. R. Grzybowski, dr E. Gorloff, dr L. Burzyńska-Wentland, dr A. Kołakowski, mgr Mariusz Brodnicki i mgr Anna Paszkowska.

Wiele uwagi gdańscy historycy wychowania poświęcają kształtowaniu się ideologii wychowawczych w Polsce na przestrzeni dziejów. Specjalizuje się w nich przede wszystkim prof. UG, dr hab. Krzysztof Jakubiak ${ }^{32}$. W polu podejmowanych przez niego dociekań dużo miejsca zajmują problemy odnoszące się do ideologii wychowawczej ruchu piłsudczykowskiego i pedagogiki katolickiej w II Rzeczypospolitej. Interesują go ponadto: zagadnienia wychowania rodzinnego oraz kształtowania się relacji rodziny i szkoły w polskiej teorii i praktyce edukacyjnej XIX i XX w.; dzieje nauczania domowego w rodzinach polskich od XVIII do początków XX w.; ksztaltowanie się historii wychowania i jej metodologii oraz pedagogiki ogólnej, teorii wychowania, filozofii wychowania i pedeutologii jako dyscyplin naukowych w Polsce. Nowym wątkiem badawczym są dzieje wychowania gospodarczego społeczeństwa polskiego w okresie zaborów (w tym głównie $\mathrm{z}$ terenu zaboru pruskiego) oraz w latach $I$ I Rzeczypospolitej.

Już w pierwszych latach działalności Katedry jej pracownicy zaczęli gromadzić dokumentację oraz organizować bibliotekę zakładową, niezbędną zarówno do prowadzenia własnych prac naukowych, jak i właściwego kierowania seminariami magisterskimi. Tylko w okresie 1959-1968 zgromadzili specjalistyczny księgozbiór historyczno-pedagogiczny o objętości 600 woluminów oraz założyli archiwum obejmujące rękopisy i starodruki dotyczące dziejów oświaty i wychowania na Pomorzu Gdańskim. Ponadto wykonali 9000 zdjęć mikrofilmowych z trudno dostępnych akt i starodruków, opracowali bibliografię historii oświaty i wychowania na Pomorzu Gdańskim za okres XX-lecia PRL. W omawianym okresie w obrębie Katedry opracowano też koncepcję utworzenia muzeum historii oświaty - instytucji gromadzącej pamiątki z dziedziny kultury materialnej i duchowej - związane z dziejami oświaty i wychowania ${ }^{33}$.

\footnotetext{
${ }^{32}$ Prof. K. Jakubiak w 2007 r. przeszedł do Uniwersytetu Gdańskiego z Uniwersytetu im. Kazimierza Wielkiego w Bydgoszczy.

${ }^{33}$ APG WSP, Sprawozdanie z działalności naukowo-badawczej Wydziału Humanistycznego Wyższej Szkoły Pedagogicznej w Gdańsku za lata 1961-1968, sygn,. 1317/145, s. 11-12.
} 


\section{Kierownicy Zakładu Historii Nauki, Oświaty i Wychowania}

Kierunek i postęp badań prowadzonych w Zakładzie Historii Wychowania w znacznym stopniu determinowała osoba kierownika Katedry, a później Zakładu Historii Oświaty i Wychowania. Warto zatem wskazać nazwiska kierowników Zakładu w okresie pięćdziesięciolecia Zakładu i przybliżyć ich sylwetki, a także kierunki podejmowanych przez nich badań oraz ważniejsze osiągnięcia naukowe.

Tabela 1. Kierownicy Zakłady Historii Nauki, Oświaty i Wychowania Instytutu Pedagogiki UG

\begin{tabular}{|c|l|c|}
\hline Lp. & \multicolumn{1}{|c|}{$\begin{array}{c}\text { Tytul, stopień naukowy oraz imię i nazwisko } \\
\text { kierownika Zakładu }\end{array}$} & Lata kierowania Zakładem \\
\hline 1 & prof. dr Kazimierz Kubik & $1959-1980$ \\
\hline 2 & prof. dr hab. Klemens Trzebiatowski & $1980-1983$ \\
\hline 3 & prof. dr hab. Lech Mokrzecki & $1983-2005$ \\
\hline 4 & prof. UG, dr hab. Romuald Grzybowski & $2005-$ \\
\hline
\end{tabular}

Źródło: badania własne.

Pierwszym wykładowcą historii wychowania w środowisku naukowym Gdańska po 1945 roku był prof. dr Kazimierz Kubik (1910-1986). On też został organizatorem i pierwszym kierownikiem początkowo Katedry, a później Zakładu Historii Oświaty i Wychowania UG. Kierował nim nieprzerwanie począwszy od 1959 r. aź do swego przejścia na emeryturę w $1980 \mathrm{r}$.

Postaci prof. K. Kubika warto poświęcić więcej uwagi, tworzył on bowiem, w niełatwych dla nauki czasach, podwaliny dla rozwoju historii wychowania w Gdańsku. Urodzony 29 czerwca 1910 r. na ziemi rzeszowskiej, podstawy wykształcenia ogólnego zdobywał w bliskiej jego miejsca urodzenia Dębicy. Kolejnym etapem edukacji były studia w Pedagogium Nauczycielskim w Krakowie, przypadające na lata $1932-1934^{34}$. Po ich ukończeniu podejmuje pracę jako nauczyciel szkoły powszechnej i inspektoratu szkolnego w Krakowie. W latach 1935-1939 odbywa studia na Uniwersytecie Jagiellońskim, które wieńczy dyplomem magistra z zakresu filozofii. W okresie okupacji K. Kubik aktywnie włącza się w nurt działalności ruchu oporu. Zostaje żołnierzem Armii Krajowej i nauczycielem tajnego nauczania. Wraz z prof. Gabrielem Brzękiem organizuje Państwową Komisję Egzaminacyjną „Kuźnicy” na terenie Inspektoratu AK Rzeszów. Pełni w niej funkcję zastępcy przewodniczącego, a także wizytatora kompletów tajnego nauczania oraz wykładowcy i egzaminatora z zakresu małej i dużej matury ${ }^{35}$.

Bezpośrednio po przejściu frontu, w kwietniu 1945 r. K. Kubik przybywa do Gdańska w składzie Delegatury Ministerstwa Oświaty (tzw. grupy operacyjnej), działającej

\footnotetext{
${ }^{34}$ J. Żerko, Kazimierz Kubik (1910-1986), „Przegląd Historyczno-Oświatowy” 1987, nr 3 (117), s. 301.

${ }^{35}$ Dzięki działalności wspomnianej Komisji, Komenda obwodu w Dębicy mogła zorganizować Szkołę Podchorążych Rezerwy, którą ukończyło 54 absolwentów.
} 
pod kierownictwem dr. Stanisława Turskiego. Zadaniem grupy była reaktywacja szkolnictwa wszystkich szczebli w mieście - od szkół powszechnych do Politechniki Gdańskiej. Powierzono mu wtedy odpowiedzialne zadanie, jakim było pełnienie funkcji pierwszego inspektora szkolnego w wyzwolonym Gdańsku, a także sekretarza generalnego Politechniki Gdańskiej. Jednak pasją K. Kubika było nie tyle administrowanie oświatą, co podejmowanie badań historyczno-oświatowych, kształcenie studentów oraz stała praca nad własnym rozwojem naukowym. Potwierdzeniem tego było uzyskanie przez Niego stopnia naukowego doktora, na podstawie rozprawy pt. „Monografia dzieci rodziców bezrobotnych", napisanej pod kierunkiem prof. Zygmunta Mysłakowskiego, obronionej w dniu 31 października 1945 roku w Uniwersytecie Jagiellońskim.

W tym czasie na trwałe związał się już z Gdańskiem. W pierwszych latach po wojnie twórczo zaangażował się w pracę dydaktyczno-naukową w Państwowym Pedagogium w Gdańsku (1945-1946), a następnie w utworzonej na jego bazie Państwowej Wyższej Szkole Pedagogicznej (od września 1946 r. do sierpnia 1952 r.). Wykładał tu historię wychowania oraz organizował praktyki pedagogiczne studentów. Równolegle pracował na Politechnice Gdańskiej, w której od kwietnia 1946 r. zatrudniony był jako starszy asystent, a później adiunkt w Katedrze Psychotechniki i Naukowej Organizacji Pracy na Wydziale Mechanicznym. Natomiast od września 1951 r. do sierpnia 1952 r. pracował jako wykładowca na Wydziale Studium Przygotowawczego. W sierpniu 1952 r., na fali narastającego terroru politycznego i postępujących w ślad za nim czystek kadrowych w szkołach wyższych ${ }^{36}, \mathrm{~K}$. Kubik stał się obiektem szykan i represji ze strony władz bezpieczeństwa. Zadenuncjowany przez studenta był przesłuchiwany, a następnie aresztowany przez Urząd Bezpieczeństwa Publicznego ${ }^{37}$. Ponieważ rewizje przeprowadzone w mieszkaniu Profesora oraz w pracowni historii wychowania w WSP nie przyniosły spodziewanych przez śledczych wyników, po czteromiesięcznych przesłuchaniach K. Kubika zwolniono $\mathrm{z}$ aresztu, ale równocześnie usunięto $\mathrm{z}$ pracy zarówno $\mathrm{z}$ WSP, jak i z Politechniki Gdańskiej ${ }^{38}$. Na okres czterech lat odszedł do pracy dydaktycznej w Technikum Budowlanym i Technikum Przemysłu Spożywczego. Do działalności naukowo-dydaktycznej w WSP w Gdańsku K. Kubik wrócił w 1956 r., na fali odwilży politycznej w Polsce. Rozpoczął się wtedy drugi, zasadniczy etap jego intensywnej pracy naukowej, która znalazła odzwierciedlenie w imponującym dorobku naukowym. Na tej podstawie K. Kubik w maju 1959 roku uzyskał tytuł docenta, natomiast w maju $1966 \mathrm{r}$. tytuł profesora nadzwyczajnego.

Zainteresowania badawcze K. Kubika grupowały się przede wszystkim wokół historii oświaty, kultury i nauki na Pomorzu Gdańskim oraz historii szkolnictwa morskiego ${ }^{39}$.

\footnotetext{
${ }^{36}$ R. Grzybowski, Dobór $i$ wymiana kadry nauczycielskiej Wyższej Szkoły Pedagogicznej w Gdańsku w latach 1946-1956, „Rocznik Gdański” t. LVIII, 1998, z. 2, s. 112-113.

${ }^{37} \mathrm{Z}$ informacji prof. K. Kubika przekazanej magistrantom w połowie lat 70. (wśród których zajajdował się autor tego opracowania) wynikało, że przedmiotem donosu do UB był dowcip („wic"- jak to określił Profesor) polityczny, opowiedziany studentom na wykładzie.

${ }^{38}$ Por. Wspomnienia dr Jerzego Szewsa, pierwszego asystenta i jednego z pierwszych doktorantów K. Kubika, „Zeszyty Naukowe UG, Pedagogika, Historia Wychowania” 1997, nr 25, s. 191.

${ }^{39}$ K. Kubik, Historia szkolnictwa morskiego w Polsce, Gdańsk 1973; idem, Szkolnictwo morslie w Polsce XVI-XVII wieku, w: Materiały z Sesji Komisji Morskiej \{w Gdańsku\}, red. E. Górecka, Warszawa 1969, s. 21-34.
} 
Punktem wyjścia w jego pracy naukowej stały się zainteresowania polską szkołą prywatną w dawnym Gdańsku ${ }^{40}$. W dalszych dociekaniach K. Kubik skoncentrował się na działalności Gdańskiego Gimnazjum Akademickiego ${ }^{41}$, poddając ocenie m.in. dorobek wybranych wybitnych profesorów tej szkoły ${ }^{42}$. K. Kubik prowadził dociekania naukowe także w innych obszarach. Bliska była mu problematyka komeniologiczna, związana recepcją myśli Jana Amosa Komeńskiego na Pomorzu w XVII w. ${ }^{43}$; analizował problematykę wychowania morskiego w harcerstwie ${ }^{44}$, rozwoju rzemiosła oraz życia kulturalnego i społecznego Gdańska w XVI-XIX w. oraz szkolnictwa polskiego w Wolnym Mieście Gdańsku ${ }^{45}$. Podejmował także badania związane $\mathrm{z}$ dziejami szkolnictwa i wychowania na Pomorzu po 1945 r. $^{46}$

Kierując w latach 1959-1980 Katedrą, a później Zakładem Historii Oświaty i Wychowania, prof. K. Kubik wytrwale otwierał nowe pola badawcze ${ }^{47}$. Jest autorem 211 publikacji naukowych, w tym 6 prac zwartych ${ }^{48}$. Wypromował 20 doktorów oraz ponad 300 magistrów. Z grona jego doktorantów trzy osoby uzyskały stopień doktora habilito-

\footnotetext{
${ }^{40}$ K. Kubik, Polska szkola prywatna w dawnym Gdańsku (od potowy XVI do połowy XIX wieku), Gdynia 1963.

${ }^{41}$ W pionierskiej pracy zatytułowanej: Gdańskie Gimnazjum Akademickie. Księga Pamiqtkowa dla uczczenia czterechsetnej rocznicy zatożenia Gimnazjum Gdańskiego 1558-1958 (Gdynia 1959), znalazły się w większości artykuły K. Kubika, takie jak: Kalendariologia profesora Pawła Patera; Sylwetka Profesora Pawla Patera; Rola Gimnazjum Akademickiego w rozwoju nauk ścistych w Gdańsku; Wspótpraca Gimnazjum Akademickiego z Towarzystwem Przyrodniczym w Gdańsku. Por. też: K. Kubik, Gdańskie Gimnazjum Akademickie, w: Historia wychowania, red. Ł. Kurdybacha, t. I, Warszawa 1965 , s. $387-391$.

${ }^{42}$ K. Kubik, Joachim Pastorius gdański pedagog XVII wielu, Gdańsk 1970; idem: Daniel Gabriel Fahrenheit - fizyk gdański, „Gdańskie Zeszyty Humanistyczne” 1964, nr 12, s. 221-243; idem, Koncepcje naukowe Henryka Kühna przedstawiciela gdańskiego Oświecenia, „Gdańskie Zeszyty Humanistyczne” 1966, Filozofia, z. 2, s. 111-174; idem, Paweł Pater, w: Stownik biograficzny pracowników ksiqżki polskiej, Warszawa-Lódź 1972, s. 661.

${ }^{43}$ K. Kubik, Wpływ Jana Amosa Komeńskiego na wykształcenie się koncepcji dydaktyczno-wychowawczej na Pomorzu Gdańskim w XVII wieku, w: Jan Amos Komeński a problemy wspótczesnej pedagogiki, Poznań 1974 , s. $9-35$.

${ }^{44}$ K. Kubik, Wychowanie morskie harcerstwa polskiego $w$ okresie międzywojennym, ,Studia Pedagogiczne" XXXVII: Wspótczesne innowacje $w$ systemie oświaty $i$ wychowania, pod red. R. Miller, Wrocław-Warszawa-Krakb́w-Gdańsk 1976, s. 183-190.

${ }^{45}$ K. Kubik, „Macierz Szkolna" w Wolnym Mieście Gdańsku, "Komunikaty Instytutu Bałtyckiego": Studia $z$ dziejów Gdańska 1918-1939, Gdańsk 1975, s. 185-201; idem, Gimnazjum polskiej Macierzy Szkolnej w Gdańsku (1922-1939), w: Księga pamiqtkowa pięćdziesięciolecie założenia Gimnazjum, pod red. B. Janika, cz. 1, Gdańsk 1976.

${ }^{46}$ K. Kubik, Szkolnictwo województwa gdańskiego w okresie Polski Ludowej (1945-1963), „Gdańskie Zeszyty Humanistyczne" 1965, R. 7.

${ }^{47}$ J. Żerko, Profesor Kazimierz Kubik, pionier organizator środowiska naukowego historyków oświaty i wychowania w Gdańsku, w: Oświata, wychowanie i kultura fizyczna rzeczywistości społeczno-politycznej Polski Ludowej (1944-1989), pod red. R. Grzybowskiego, Torun 2004, s. 360.

${ }^{48}$ Por. m.in.: K. Kubik, Polska szkoła prywatna w dawnym Gdańsku, Gdańsk 1963; idem, Wybór źródel do dziejów oświaty i nauki Pomorza Gdańskiego w XVII XVIII wieku, Gdańsk 1965; idem, Joachim Pastorius gdański pedagog XVII wieku, Gdańsk 1970; idem, Historia szkolnictwa morskiego, Gdańsk 1973; K. Kubik, L. Mokrzecki, Trzy wieki nauki gdańskiej. Szkice z dziejów XVI-XVIII wieku, Gdańsk 1969 (wydanie drugie tej pracy, zmienione i poszerzone: Trzy wieki nauki gdańskiej. Szkice z dziejów od XVI do XVIII wieku, Wrocław 1976).
} 
wanego, a jedna - Lech Mokrzecki - tytuł profesora zwyczajnego ${ }^{49}$. Stopień doktora habilitowanego zdobył także inny z magistrantów K. Kubika, który pracę doktorską napisał już pod kierunkiem prof. Lecha Mokrzeckiego ${ }^{50}$.

O pozycji naukowej prof. K. Kubika decydowała zarówno ogromna wiedza, liczący się dorobek naukowy, jak i jego patriotyczna postawa, przejawiana nie tylko w okresie wojny i okupacji, lecz także w trudnych latach PRL. Odzwierciedleniem tego były funkcje pełnione w Uczelni: prodziekana (1962-64) i dziekana (1964-1968) Wydziału Humanistycznego WSP. Do 1968 roku prowadził też równolegle zajęcia dydaktyczne w UMK w Toruniu, a w latach 1975-1979 w WSP w Shupsku ${ }^{51}$.

Współpracownikiem prof. K. Kubika był prof. dr hab. Klemens Żmuda-Trzebiatowski (1913-1984). W latach 1980-1983 pełnił on funkcję kierownika Zakładu Historii Oświaty i Wychowania, przez dwie kadencje był prodziekanem Wydziału Humanistycznego UG, natomiast w latach 1978-1981 piastował stanowisko dyrektora Instytutu Pedagogiki UG.

K. Trzebiatowski urodził się i wychował w rodzinie chłopskiej, zamieszkałej w niewielkiej miejscowości w powiecie chojnickim. Od wczesnych lat dziecięcych zdradzał zainteresowania naukowe ${ }^{52}$. Nic zatem dziwnego, że po ukończeniu szkoły powszechnej kontynuował naukę - początkowo w uniwersytecie ludowym w Dalkach koło Gniezna, a następnie w seminarium nauczycielskim w Kościerzynie. Jako nauczyciel szkoły powszechnej podjął studia w Wolnej Wszechnicy Polskiej w Warszawie, na kierunku geografii. Kontynuował naukę w okresie okupacji, uczestnicząc równocześnie w pracach Tajnej Organizacji Nauczycielskiej(TON) oraz w akcjach zbrojnych Armii Krajowej. Studia wyższe ukończył już po zakończeniu II wojny światowej, uzyskując na Wydziale Pedagogicznym Wolnej Wszechnicy Polskiej stopień magistra filozofii w zakresie pedagogiki. Równolegle uzyskał też przygotowanie pedagogiczne do nauczania biologii w szkole średniej.

Po 1945 r. K. Trzebiatowski wrócił na Pomorze Gdańskie i aktywnie włączył się w nurt działalności dydaktycznej i organizacyjnej w strukturach systemu kształcenia nauczycieli oraz w nadzorze pedagogicznym. Pełnił m.in. funkcję nauczyciela i dyrektora liceum pedagogicznego w Bytowie, a następnie w Słupsku, inspektora szkolnego w Chojnicach. Brał też udział w organizowaniu Wyższego Kursu Nauczycielskiego ZNP. W latach 1955-1958 zajmował stanowisko kuratora Okręgu Szkolnego w Koszalinie, pełniąc równocześnie funkcję przewodniczącego Wojewódzkiego Komitetu Frontu Jedności Narodu. Równolegle pracował społecznie, m.in. w organizacji powiatowej Związku Nauczycielstwa Polskiego, w organizacjach kulturalnych i spółdzielczych, a także w Towarzystwie Burs i Stypendiów, w którym koncentrował się na udzielaniu pomocy

\footnotetext{
${ }^{49}$ J. Żerko, Profesor Kazimierz Kubik, w: Oświata, wychowanie, s. 360.

${ }^{50}$ Jest nim R. Grzybowski - autor prezentowanego szkicu, który pod kierunkiem prof. K. Kubika napisał prace magisterska pt. Problemy oświaty wsi na lamach „Gazety Grudziądzkiej” w latach 1894-1939, Gdańsk 1979 (mszp.).

${ }^{51}$ Ibidem, s. 360.

${ }^{52}$ L. Mokrzecki, Profesor Klemens Trzebiatowski (1913-1984), „Zeszyty Naukowe UG. Pedagogika, Historia Wychowania" 1993, nr 21, s. 156.
} 
uczącej się i studiującej młodzieży ${ }^{53}$. Społeczno-polityczny nurt działalności K. Trzebiatowskiego przerwany został w roku 1958, w którym władze komunistyczne odkryły jego konspiracyjną działalność, prowadzoną w okresie okupacji w strukturach $\mathrm{AK}$. W rezultacie został pozbawiony zarówno stanowiska kuratora, jak i usunięty z $\mathrm{PZPR}^{54}$.

W roku $1952 \mathrm{~K}$. Trzebiatowski rozpoczął pracę w Wyższej Szkole Pedagogicznej w Gdańsku, prowadząc - jako zastępca profesora - zajęcia $\mathrm{z}$ biologii. W kolejnych latach wykładał m.in. psychologię oraz pedagogikę. Jednak jego zainteresowania naukowe, wyraźnie zarysowane jeszcze $w$ trakcie studiów, koncentrowały się wokół zagadnień dotyczących historii szkolnictwa. Potwierdzeniem tego był referat wygłoszony na wspomnianej już Pomorskiej Konferencji PAN w 1954 r. Po powrocie w roku 1958 do roli nauczyciela akademickiego WSP w Gdańsku K. Trzebiatowski skoncentrował się na działalności naukowo-dydaktycznej. Interesowała go zwłaszcza problematyka historyczno-oświatowej, odnosząca się do terenu Pomorza. W 1960 r., na Wydziale Pedagogicznym Uniwersytetu Warszawskiego, uzyskał stopień doktora nauk humanistycznych na podstawie rozprawy pt. Oświata i szkolnictwo polskie na Pomorzu Zachodnim w pierwszej polowie XX wieku (opublikowanej drukiem w1961) ${ }^{55}$. Odtąd efektywnie łączył obowiązki pracownika naukowo-dydaktycznego, zatrudnionego w Katedrze Historii Oświaty i Wychowania WSP z zadaniami wynikającymi z pelnionych funkcji prodziekana Wydziału Humanistycznego, kierownika Zakładu Praktyk, zastępcy dyrektora oraz po latach - dyrektora Instytutu Pedagogiki, a w ostatnich trzech latach jego pracy - kierownika Zakładu Historii Oświaty i Wychowania. Intensywna praca naukowa K. Trzebiatowskiego zaowocowała początkowo docenturą etatową (1969 r.), a następnie uzyskaniem w roku 1971 stopnia naukowego doktora habilitowanego, na podstawie rozprawy Szkolnictwo powszechne w Polsce w latach 1918-1939 (Wrocław 1970). Praca ta była w tym czasie uznawana za najpełniejszą syntezę badań nad szkolnictwem polskim w okresie międzywojennym. Na podstawie pomnażanego systematycznie dorobku naukowego, w tym książki Organizacja szkolnictwa w Polsce Ludowej, K. Trzebiatowskiemu nadano w 1977 r. tytuł profesora nadzwyczajnego.

W całym okresie aktywności zawodowej dociekania naukowe prof. K. Trzebiatowskiego koncentrowały się wokół problemów oświaty i wychowania na Pomorzu Zachodnim oraz na terenie Powiśla. Naukowej penetracji poddał on zarówno zasady organizacji szkolnictwa na tym terenie, jak i krańcowo niekorzystną dla Polaków politykę szkolną rządu pruskiego. Podejmował też problemy strajków szkolnych w Prusach Zachodnich w początkach XX w. Ponadto $\mathrm{K}$. Trzebiatowski z powodzeniem analizował zagadnienia organizacji szkolnictwa w Polsce nie tylko w okresie międzywojennym, lecz i w latach PRL. Swe ustalenia odnosił i ukazywał na tle systemów oświatowych w innych krajach europejskich. Brał też aktywny udział w badaniach naukowych rozwijanych w latach PRL w ramach tzw. tematów węzłowych, międzyresortowych i resortowych, zwłaszcza problemów związanych z modernizacją oświaty w tzw. rozwiniętym społeczeństwie

\footnotetext{
${ }^{53}$ K. Kubik, Klemens Żmuda Trzebiatowski (1913-1984), „Przegląd Historyczno-OŚwiatowy” 1985, nr 1(107), s. 57-62.

${ }^{54}$ L. Mokrzecki, Profesor Klemens Trzebiatowski (1913-1984), s. 162.

${ }^{55}$ K. Kubik, Klemens Żmuda Trzebiatowski (1913-1984), s. 57-62.
} 
socjalistycznym ${ }^{56}$. Przedmiotem dociekań badawczych K. Trzebiatowskiego stali się teoretycy myśli pedagogicznej oraz ideolodzy i politycy, tacy jak Lenin oraz A. Diesterweg. Zajmowała go także problematyka dotycząca rozwoju ruchu nauczycielskiego. Ujmował ją w odniesieniu do całego kraju oraz do terenu Pomorza. Podejmował wątki badawcze odnoszące się do dokształcania i doskonalenia kadr oświatowych, zwłaszcza w zakresie kierowania i zarządzania oświatą. Potwierdzeniem pracowitości prof. dr hab. K. Trzebiatowskiego jest około 140 prac naukowych, które składają się na jego dorobek naukowy, wysoko ceniony zarówno przez kolejne pokolenia badaczy dziejów oświaty, jak i studentów ${ }^{57}$.

Prof. K. Trzebiatowski aktywnie uczestniczył też w kształceniu młodej kadry naukowej: wypromował 8 doktorów oraz ponad 200 magistrów; recenzował kilkanaście 10 rozpraw doktorskich oraz kilka rozpraw habilitacyjnych. Był członkiem wielu towarzystw naukowych, rad naukowych i instytucji pedagogiczno-oświatowych. Wśród nich wymienić należy członkostwo Komitetu Nauk Pedagogicznych PAN, Instytutu Pedagogicznego, Zespołu Badań Nautologicznych PAN, Komitetu Redakcyjnego „Monografii z Dziejów Oświaty PAN"58.

Swoistym podsumowaniem postawy i dorobku życiowego prof. K. Trzebiatowskiego może być odnosząca się do niego uwaga K. Kubika: „We wszystkich poczynaniach - tak administracyjnych, jak i dydaktyczno-oświatowych - cieszył się popularnością i autorytetem zarówno wśród młodzieży, jak i współpracowników"59.

Grono współpracowników prof. K. Kubika systematycznie powiększali jego uczniowie - doktoranci, którzy w strukturach Zakładu Historii Wychowania uzyskali nie tylko kolejne stopnie naukowe, ale budowali też własną tożsamość naukową. Niewątpliwie najwybitniejszym wychowankiem K. Kubika okazał się prof. dr hab. Lech Mokrzecki (ur. w 1935 r.). W latach 1983-2005 pełnił on nieprzerwanie funkcję kierownika Zakładu Historii Nauki, Oświaty i Wychowania. Ponadto w latach 1978-1981 piastował stanowisko wicedyrektora Instytutu Pedagogiki UG. Natomiast w roku 1981 został wybrany na stanowisko dyrektora Instytutu. Kierował nim do 1991 roku. W latach 1985-1987 pełnił też funkcję prorektora UG do spraw studenckich.

\footnotetext{
${ }^{56} \mathrm{Z}$ tego zakresu opublikował m.in. Ekspertyzę istniejq̨cego stanu zarzqdzania oświata, w: $Z$ badań nad zarzq̨dzaniem oświatą. Problem węzłowy, Warszawa 1978; Czynniki natury organizacyjnej i pedagogicznej warunkujące nowy system kierowania szkoła, „Studia Pedagogiczne” 1980 i inne.

${ }^{57} \mathrm{~K}$. Trzebiatowski jest autorem około 140 prac naukowych, w tym kilku znaczących książek: Oświata i szkolnictwo polskie na Pomorzu Zachodnim w pierwszej połowie XX wieku (1900-1939), Poznań 1961; idem, Organizacja i podstawy prawne szkolnictwa, cz. I - Gdańsk 1964, cz. II - Gdańsk 1966, cz. III Gdańsk 1968, cz. IV - Gdańsk 1969; idem, Szkolnictwo powszechne w Polsce w latach 1918-1932, Wrocław 1970; idem, Organizacja szkolnictwa w Polsce Ludowej, Warszawa 1972; idem, Poradnik organizacyjno-ekonomiczny kierownika szkoty, Warszawa 1972 (wspólnie z K. Podoskim), wydanie II zmienione Warszawa 1975; idem, Oświata $i$ wychowania w XX wieku (do 1975 roku), Gdańsk 1975; idem, System oświatowy Polskiej Rzeczypospolitej Ludowej na tle porównawczym (Źródta). Skrypt uczelniany, wspólnie z J. Żerko); idem, Szkolnictwo w województwie pomorskim w latach 1920-1939, Wrocław 1986.

${ }^{58}$ Instytut Pedagogiki UG z okazji Jubileuszu 70 rocznicy urodzin poświęcił Mu specjalny numer (13) „Zeszytów Naukowych Wydziału Humanistycznego, Seria Pedagogika, Historia Wychowania”. znajduje się w nim m.in. bibliografia prac $\mathrm{K}$. Trzebiatowskiego.

${ }^{59}$ K. Kubik, Klemens Żmuda Trzebiatowski (1913-1984), s. 61.
} 
L. Mokrzecki urodził się w 1935 r. w Warszawie, dzieciństwo spędził w Wilnie, skąd w ramach repatriacji, po kilkuletniej wędrówce trafił wraz z matką do Torunia. Tam uczęszczał do I Gimnazjum i Liceum im. Mikołaja Kopernika. W roku 1951 uzyskał maturę. Równolegle uczył się gry na wiolonczeli w Państwowej Średniej Szkole Muzycznej. Ukończył ją w 1955 r., a następnie podjął studia w klasie wiolonczeli Państwowej Wyższej Szkoły Muzycznej w Sopocie ${ }^{60}$. W latach 1952-1956 studiował historię w Uniwersytecie Mikołaja Kopernika w Toruniu. Ten etap edukacji zamknął obroną pracy magisterskiej pt. „Sprawa Chłopska w kodeksie Andrzeja Zamojskiego”, napisanej pod kierunkiem prof. Jadwigi Lechickiej. Następnie przeniósł się do Gdańska, gdzie przez dłuższy czas umiejętnie łączył pracę nauczyciela historii, śpiewu i gry na wiolonczeli. W latach 1959-1967 był też wiolonczelistą w Państwowej Operze i Filharmonii Bałtyckiej w Gdańsku.

W roku 1966 podjął pracę w Katedrze Historii Oświaty i Wychowania w WSP ${ }^{61}$. Tam też, pod kierunkiem prof. K. Kubika przygotował pracę doktorską, zatytułowaną „Problematyka nauczania historii w Gdańskim Gimnazjum Akademickim w XVI i XVII wieku". Tytuł doktora uzyskał w 1967 roku. W roku 1975 habilitował się na podstawie rozprawy $W$ kręgu prac historyków gdańskich XVII w. (Gdańsk 1974). W roku 1986 uzyskał tytuł profesora nadzwyczajnego na podstawie ksiąziki Poczqtki wiedzy o morzu w dawnej Rzeczypospolitej. Problematyka morska w nauce gdańskiej doby Baroku i Oświecenia. W roku 1993 uzyskał mianowanie przez ministra na stanowisko profesora zwyczajnego. Podstawą decyzji ministra była książka: Tradycje nauczania historii do końca XVI wieku. Wybrane kraje i problemy. Potwierdzeniem wysokiej pozycji L. Mokrzeckiego w świecie nauki było nadanie mu w roku 1998 tytułu doktora h.c. Uniwersytetu w Linköpingu ${ }^{62}$.

Prof. L. Mokrzecki przez wiele lat umiejętnie łączył pracę naukową z karierą zawodowego muzyka. Pod kierunkiem prof. K. Kubika rozpoczął intensywną pracę naukową, rezultatem której jest imponujący dorobek naukowy ${ }^{63}$. Problematyka badawcza podejmowana przez prof. L. Mokrzeckiego dostrzegalna jest $w$ kilku nurtach ${ }^{64}$. Pierwszy $\mathrm{z}$ nich obejmuje dociekania nad nauczaniem historii w Gdańsku ${ }^{65}$. Po latach L. Mokrzecki poszerza swe zainteresowania $w$ tej mierze na teren całej Rzeczpospolitej oraz na wybrane państwa ówczesnej Europy ${ }^{66}$. Drugi nurt badań L. Mokrzeckiego skupia się na problema-

\footnotetext{
${ }^{60}$ Dyplom artysty muzyka uzyskał w 1962 r., natomiast w roku 1964 został magistrem sztuki.

${ }^{61}$ Por.: K. Puchowski, J. Żerko, Profesor Lech Mokrzecki - badacz dziejów nauki, kultury i oświaty, w: W stużbie historii nauki, kultury $i$ edukacji. Księga Pamiatkowa Dedykowana Prof. Lechowi Mokrzyckiemu z Okazji Jubileuszu Pięćdziesięciolecia prac zawodowej, pod red. R. Grzybowskiego i T. Maliszewskiego, wyd. II poprawione i uzupełnione, Gdańsk 2008, s. 17-24.

${ }^{62}$ K. Puchowski, J. Żerko, Profesor Lech Marian Mokrzecki - badacz dziejów nauki, kultury i oświaty, w: W stużbie historii nauki, kultury $i$ edukacji. Ksiega Pamiqtkowa dedykowana Prof. Lechowi Mokrzeckiemu, pod red. R. Grzybowskiego i T. Maliszewskiego, Gdańsk 2006, s. 17-24.

${ }^{63}$ Ibidem.

${ }^{64}$ Por. Publikacje Profesora Lecha Mokrzeckiego (lata 1951-2006), w: W shużbie historii nauki, kultury $i$ edukacji. Ksiega Pamiatkowa, s. 27-60.

${ }^{65}$ L. Mokrzecki, Studium z dziejów nauczania historii. Rozwój dydaktyki przedmiotu w Gdańskim Gimnazjum Akademickim do schytku XVII w., Wrocław 1973.

${ }^{66}$ L. Mokrzecki, Tradycje nauczania historii do końca XVI wieku. Wybrane kraje i problemy, Gdańsk 1992.
} 
tyce dziejopisarstwa mieszczańskiego $\mathrm{w} \mathrm{Gdańsku}^{67}$ oraz zagadnieniach metodologicznych. Dopełnieniem dociekań nad rozwojem nauki i kultury w Gdańsku w okresie Pierwszej Rzeczpospolitej z jednej strony było dzieło, napisane wspólnie z K . Kubikiem, pt. Trzy wieki nauki gdańskiej ${ }^{68}$, $\mathrm{z}$ drugiej zaś starannie opracowane biogramy uczonych gdańskich (Joachima Pastoriusa, Jana Schulza - Szuleckiego oraz Bartłomieja Eckermanna), zamieszczone w Polskim słowniku biograficznym oraz Stowniku biograficznym Pomorza Nadwiślańskiego. Kolejny obszar badawczy w dorobku L. Mokrzeckiego stanowi problematyka morska. Interesowała go zwłaszcza wiedza mieszkańców dawnej Rzeczpospolitej o morzu, skonfrontowana z kształtującymi się w Gdańsku naukowymi zainteresowaniami problematyką morską ${ }^{69}$. Swoistą summą dorobku prof. L. Mokrzeckiego, odnoszącego się do omawianych zagadnień, jest książka pt. Wokót staropolskiej nauki i oświaty. Gdańsk - Prusy Królewskie - Rzeczpospolita, (Gdańsk 2001). Przybliża ona jego ustalenia badawcze, zawarte dotąd w licznych artykułach naukowych, rozproszonych w czasopismach i pracach zbiorowych.

Dużo uwagi L. Mokrzecki poświęcał także dziejom kultury i oświaty muzycznej zarówno w Gdańsku, jak i poza jego granicami ${ }^{70}$.

Pełniąc funkcję kierownika Zakładu ${ }^{71} \mathrm{~L}$. Mokrzecki nie tylko doprowadził do zmiany jego nazwy na: Zakład Historii Nauki, Oświaty i Wychowania, ale także znacznie rozszerzył i pogłębił problematykę podejmowanych w jego obrębie dociekań naukowych. Przede wszystkim sam prowadził (i prowadzi) wielowątkowe, intensywne badania naukowe: jest autorem 9 książek, około 450 artykułów, rozpraw i innych publikacji naukowych i ponad 70 publikacji popularnonaukowych, poświęconych popularyzacji muzyki poważnej ${ }^{72}$. Do tej pory brał udział w około 100 przewodach doktorskich i habilitacyjnych. Pod jego kierunkiem 10 adeptów nauki napisało prace doktorskie ${ }^{73}$. Ponadto wypromował jednego doktora honoris causa. Należy dodać, że prof. L. Mokrzecki jest członkiem wielu krajowych i międzynarodowych organizacji i towarzystw naukowych. Jest też członkiem redak-

\footnotetext{
${ }^{67}$ L. Mokrzecki, W kręgu prac historyków gdańskich XVII wieku, Gdańsk 1974, idem, Problemy metodologiczne badań nad świadomościq historycznq okresu staropolskiego, w: Świadomość historyczna jako przedmiot badań historycznych, socjologicznych $i$ historyczno-dydaktycznych. Materiaty z konferencji naukowej, red. J. Maternicki, Warszawa 1985, s. 165-169. Por. także: L. Mokrzecki, J. Żerko, Regionalizm w badaniach i nauczaniu historii wychowania, „Rozprawy z Dziejów Oświaty” 1989, t. 32, s. 197-203.

${ }^{68}$ K. Kubik, L. Mokrzecki, Trzy wieki nauki gdańskiej. Szkice dziejów XVI-XVIII wieku, Gdańsk 1969 (wydanie drugie 1976).

${ }^{69}$ L. Mokrzecki, Poczqtki wiedzy o morzu $w$ dawnej Rzeczypospolitej. Problematyka morska $w$ nauce gdańskiej doby baroku i Oświecenia, Wrocław-Warszawa-Kraków-Gdańsk-Lódź 1983.

${ }^{70}$ L. Mokrzecki, Kontakty artystyczne i naukowe Gdańska z zagranica w XVI-XVIII wieku, w: Muzyka w Gdańsku dawniej $i$ dziś. Cz. 2: Kultura muzyczna Pólnocnych Ziem Polski, t. 6, pod red. J. Krassowskiego, Gdańsk 1992, s. 7-22; idem, Polskie konserwatorium Muzyczne w Gdańsku (1929-1939), „Gdańskie Zeszyty Humanistyczne. Prace Pomorzoznawcze" 1966, nr 13, s. 121-139.

${ }^{71}$ W latach 1978-1981 pehił funkcję wicedyrektora, a w latach 1981-1991 funkcję dyrektora Instytutu Pedagogiki (w wyniku wyborów). Ponadto w latach 1985-1987 powołany zostal przez Senat UG na stanowisko prorektora UG do spraw studenckich.

${ }^{72}$ Por. Publikacje Profesora Lecha Mokrzeckiego (lata 1951-2006), w: W shużbie historii nauki, kultury i edukacji. Ksiega Pamiątkowa, s. 27-60.

${ }^{73}$ K. Bartnicka, Jubileusz Profesora Lecha Mokrzeckiego - laudacja w Dworze Artusa w Gdańsku, czerwiec 2005, w: W stużbie historii nauki, kultury i edukacji. Ksiega Pamiqtkowa, s. 13-16.
} 
cji wielu periodyków naukowych. Wielokrotnie nagradzany i odznaczany, m.in. Krzyżem Kawalerskim Orderu Odrodzenia Polski.

$\mathrm{Z}$ okazji Jubileuszu 60 rocznicy urodzin L. Mokrzeckiego współpracownicy z Zakładu Historii Nauki, Oświaty i Wychowania przygotowali księgę pamiątkową pt. Szlakami przeszłości i czasów współczesnych. Księga ofiarowana Profesorowi Lechowi Mokrzeckiemu z okazji Jego Jubileuszu, pod red. K. Puchowskiego i J. Żerki (Gdańsk 1996). Okazją do wydania kolejnej księgi pamiątkowej, dedykowanej L. Mokrzeckiego był Jubileusz z okazji pięćdziesięciolecia pracy zawodowej. Uczniowie i współpracownicy przygotowali z tej okazji tom pt. W stużbie historii nauki, kultury i edukacji. Księga Pamiatkowa dedykowana Prof. Lechowi Mokrzeckiemu z Okazji Jubileuszu Pięćdziesięciolecia pracy zawodowej, pod redakcją R. Grzybowskiego i T. Maliszewskiego (Gdańsk 2006; wydanie II uzupełnione i poprawione Gdańsk 2008). W pracach tych zawarto m.in. pełną, dotychczasową bibliografię prac prof. L. Mokrzeckiego.

Następcą L. Mokrzeckiego na stanowisku kierownika Zakładu w roku 2005 został prof. UG, dr hab. Romuald Grzybowski (ur. 1953 r.).

\section{Pracownicy naukowo-dydaktyczni Zakladu Historii Nauki, Oświaty i Wychowania ${ }^{74}$}

Jednym z pierwszych wspótpracowników K. Kubika w Katedrze Historii Oświaty i Wychowania był dr Jerzy Szews (ur. 1925 ). Wielkopolanin, urodzony w Gnieźnie w rodzinie urzędnika miejskiego, ukończył pedagogikę na Uniwersytecie Poznańskim. Jako student IV roku studiów był asystentem prof. Stefana Wołoszyna w Katedrze Pedagogiki. Pod jego kierunkiem napisał też pracę magisterska. Po studiach przez dziesięć lat zdobywał doświadczenie pedagogiczne jako nauczyciel pedagogiki i psychologii $\mathrm{w}$ liceach pedagogicznych w Szklarskiej Porębie oraz w Wejherowie. We wrześniu 1961 r. J. Szews został zatrudniony na stanowisku asystenta w Katedrze Historii Oświaty i Wychowania. Praktyka nauczycielska dr. J. Szewsa oraz poczucie więzi z doświadczeniem ludności polskiej z terenu Wielkopolski i Pomorza, poddanej w okresie zaborów zorganizowanej akcji germanizacyjnej, wpłynęły na rozwój jego zainteresowań naukowych. W pierwszym okresie pracy koncentrowały się one wokół problematyki jawnego nauczania języka polskiego $\mathrm{w}$ gimnazjach funkcjonujących na terenie zaboru pruskiego. $\mathrm{Z}$ tego zakresu, pod kierunkiem prof. K. Kubika, napisał pracę doktorską, zatytułowaną: „Język polski w szkolnictwie średnim Pomorza Gdańskiego w latach 1815-1920"75. Po uzyskaniu awansu na stanowisko adiunkta J. Szews prowadził wykłady i seminaria magisterskie z zakresu historii wychowania. W latach 1967-1987 wypromował ponad 100 magistrów pedagogiki, specjalizujących się w historii oświaty i wychowania.

\footnotetext{
${ }^{74}$ Szerzej omawiam sylwetki tylko tych pracowników, którzy przeszli na emeryturę lub zmarli.

${ }^{75}$ Obrona odbyła się 29 VI 1967 r.
} 
Tabela 2. Pracownicy Zakładu Historii nauki, Oświaty i Wychowania zatrudnieni przed $1980 \mathrm{r}$.

\begin{tabular}{|c|l|l|l|}
\hline Lp. & \multicolumn{1}{|c|}{ Imię i nazwisko } & Tytuł - stopień naukowy & \multicolumn{1}{c|}{ Lata pracy w ZHN,OiW } \\
\hline 1 & Kazimierz Kubik & prof. dr & $1946-1952 ; 1956-1986$ \\
\hline 2 & Klemens Trzebiatowski & prof. dr hab. & $1952-1984$ \\
\hline 3 & Bolesław Pleśniarski & mgr (z-ca prof.) & $1952-1958$ (drugi etat) \\
\hline 4 & Jerzy Szews & dr (adiunkt) & $1961-1987$ \\
\hline 5 & Lech Mokrzecki & prof. zw. dr hab. & $1966-2005$ (od 2005 emerytura, na czéści etatu) \\
\hline 6 & Józef Żerko & dr (adiunkt) & $\begin{array}{l}1972-2007 \text { (od 2007 emerytura, na godzi- } \\
\text { nach zleconych) }\end{array}$ \\
\hline
\end{tabular}

Źródło: badania własne.

Już jako dojrzały badacz J. Szews poszerzył swoje zainteresowania badawcze m.in. o problematykę tajnego nauczania języka polskiego, organizowanego w odpowiedzi na całkowitą likwidację (w roku 1901), nauki tego przedmiotu w pruskich szkołach średnich na Pomorzu Gdańskim. Miejscem zakonspirowanej edukacji języka polskiego i wychowania patriotycznego stały się tajne organizacje samokształceniowe, funkcjonujące pod nazwą Towarzystwa Filomatów Towarzystwa Tomasza Zana. W toku dwudziestoletniej pracy badawczej J. Szews zrekonstruował historię wspomnianych, tajnych związków filomackich na Pomorzu w latach $1830-1920 . Z$ tego zakresu opublikował pionierskie pra$\mathrm{ce}^{76}$, w tym dzieło stanowiące ukoronowanie jego wieloletnich badań: Filomaci pomorscy. Tajne związi młodzieży polskiej na Pomorzu Gdańskim w latach 1830-1920, (Warszawa 1992). Dopełnieniem tego nurtu zainteresowań naukowych J. Szewsa są prace biograficzne, obejmujące przede wszystkim sylwetki członków wspomnianych, tajnych związków młodzieży gimnazjalnej. W tym cyklu opracował i opublikował ponad 120 biogramów w znaczących słownikach biograficznych ${ }^{77}$.

Ważną dziedzinę działalności naukowej dr J. Szewsa stanowią prace bibliograficzne. Odzwierciedleniem tego nurtu Jego zainteresowań jest bibliografia historii oświaty $\mathrm{i}$ wychowania na Pomorzu Gdańskim, obejmująca lata 1945-1975 ${ }^{78}$. Przygotował też, we współpracy z Henrykiem Polakiem, bibliografię prac dotyczących oświaty polskiej w Wolnym Mieście Gdańsku ${ }^{79}$. Ponadto J. Szews jest autorem bibliografii dorobku na-

\footnotetext{
${ }^{76}$ J. Szews, Filomaci pomorscy. Księga pamiq̨tkowa, Wejherowo 1975; idem, Towarzystwo Tomasza Zana w Rogoźnie 1873-1918, Rogoźno 1987.

${ }^{77}$ Por. J. Szews, M. Paluszkiewicz, Stownik biograficzny członków tajnych towarzystw gimnazjalnych w Wielkim Księstwie Poznańskim 1850-1918, Poznań 2000; Słownik biograficzny Ziemi Lubawskiej 1244-2000, Lubawa 2000. Biogramy publikował także w kolejnych tomach Polskiego stownika biograficznego, Stownika biograficznego Pomorza Nadwiślańskiego; w Stowniku pracowników ksiązki polskiej (Warszawa Łódź 1972), Encyklopedii katolickiej i innych wydawnictwach.

${ }^{78} \mathrm{~J}$. Szews, Bibliografia historii oświaty $i$ wychowania na Pomorzu Gdańskim. Publikacje z lat 1945-1963, „Przegląd Historyczno-Oświatowy”, 1964, nr 2; idem: Bibliografia... Publikacje z lat 1964-1967, PHO 1968, nr 2; idem, Bibliografia... . Publikacje z lat 1968-1975 oraz uzupetnienia za lata 1945-1967, PHO 1976, nr 4; idem, Bibliografia historii oświaty $i$ wychowania na Pomorzu Gdańskim. Uzupełnienia, PHO 1977, nr 2.

${ }^{79}$ J. Szews, Bibliografia szkolnictwa $i$ oświaty polskiej $w$ Wolnym Mieście Gdańsku. Materiały $i$ opracowanie 1920-1970, „Gdańskie Zeszyty Humanistyczne”, Seria Pedagogika, Psychologia, Historia Wychowania 1970 , z. 4.
} 
ukowego pedagogów gdańskich, w tym K. Kubika, L. Bandury, K. Trzebiatowskiego i W. Frąckowiaka. Kolejnym obszarem badań prowadzonych przez dr J. Szewsa stały się dzieje szkół, a przede wszystkim zakładów kształcenia nauczycieli, działających na Pomorzu Gdańskim oraz poza jego granicami w XIX i XX w. ${ }^{80}$ Warto podkreślić, że wiele ze swych znaczących prac dr J. Szews napisał już po przejściu w 1987 r. na rentę (z powodu choroby oczu), a następnie na emeryturę. Do 2008 r. J. Szews opublikował ponad 200 prac, w tym 8 książek $^{81}$.

Najmłodszym z grona współpracowników, doktorantów prof. K. Kubika, zatrudnionym w Zakładzie Historii Oświaty i Wychowania - pierwszym miejscu pracy - był dr Józef Żerko (ur. 1942) ${ }^{82}$. Absolwent Liceum Pedagogicznego w Koszalinie (1954), uzupełniał swe wykształcenia w Studium Nauczycielskim w Słupsku, by w roku 1963 podjąć studia na kierunku pedagogika w Wyższej Szkole Pedagogicznej w Gdańsku. Po ukończeniu w 1967 roku studiów wyższych przez kilka lat pracował w szkolnictwie ogólnokształcącym w Gdańsku ${ }^{83}$. W roku 1972 został zatrudniony na stanowisku starszego asystenta w Zakładzie Historii Oświaty i Wychowania. Nawiązana przez J. Żerko w trakcie studiów (za sprawą seminarium magisterskiego), współpraca naukowa z prof. K. Kubikiem zaowocowała napisaną pod jego kierunkiem dysertacją doktorską, zatytułowaną: „Kształcenie dorosłych w szkołach ogólnokształcących w województwie gdańskim w latach 1945-1975"84. W ślad za tym J. Żerko uzyskał awans na stanowisko adiunkta, które zajmował do 1987 roku. W latach 1987-2007 był zatrudniony na stanowisku starszego wykładowcy. W roku 2007 przeszedł na emeryturę.

W trakcie wieloletniej pracy w Zakładzie dr J. Żerko systematycznie poszerzał zakres swoich zainteresowań badawczych. Zajmowała go przede wszystkim problematyka dotycząca różnorakich uwarunkowań funkcjonowania szkolnictwa ogólnokształcącego dla dzieci, młodzieży i dorosłych na terenie województwa gdańskiego ${ }^{85}$. W tym kontekście podejmował też dociekania nad prawidłowościami demokratyzacji oświaty w Polsce ${ }^{86}$ oraz przybliżał rezultaty współpracy pedagogów gdańskich z uczonymi ze Szwecji ${ }^{87}$. Pod jego redakcją ukazały się prace zbiorowe poświęcone wybranym problemom funkcjonowania

\footnotetext{
${ }^{80}$ J. Szews, B. Bieszk, Kształcenie nauczycieli $i 350$ lat szkolnictwa $w$ Wejherowie, Wejherowo 1994; J. Szews, Ksiegga pamiq̨tkowa Państwowego Liceum Pedagogicznego w Szklarskiej Porębie 1947-1957, Szklarska Poręba 2003.

${ }^{81}$ Por. m.in.: J. Żerko, Profesor Kazimierz Kubik, w: Oświata, wychowanie, s. 356-369.

${ }^{82}$ Pomimo że w roku $2007 \mathrm{dr}$ J. Żerko przeszedł na emeryturę, jest stałym współpracownikiem macierzystego Zakładu Historii Nauki, Oświaty i Wychowania.

${ }^{83}$ Przez rok pracował w Szkole Podstawowej na 57 w Gdańsku, w latach 1968-1970 w V Liceum Ogólnokształcącym w Gdańsku - Oliwie. Z kolei w latach 1970-1972 pelnił funkcje zastępcy dyrektora Szkoły Podstawowej nr 67 w Gdańsku.

${ }^{84}$ Obrona odbyła się 16 czerwca 1977 r.

${ }^{85}$ J. Żerko, Szkolnictwo ogólnoksztalcq̨ce dla pracujących województwa gdańskiego w latach 1945-1975, Wrocław-Warszawa-Kraków-Gdańsk-Lódź 1986.

${ }^{86}$ "S(z)koldem" Project Papers: Democratization of Education. Experiences from Poland and Sveden, Vuxenutbildarcentrum $i$ Linköping, Edited by: H. Hovenberg, T. Maliszewski, T. Wojtowicz, J. Żerko, Linkőping 1996.

${ }^{87}$ Anthology of Social and Behavioural Sciences. 20 Years of Co-operation between the Universities in Linköping and Gdańsk, Edited by Tomasz Maliszewski, Wit J. Wojtowicz, Józef Żerko, Linköping 2005.
} 
oświaty w Polsce od XVI do XXI w. ${ }^{88}$ Przedmiotem badań J. Żerko stała się problematyka ruchu młodzieżowego, rozwijającego swą działalność na terenie województwa gdańskiego $^{89}$, a także wychowania morskiego młodzieży ${ }^{90}$ oraz resocjalizacji nieletnich ${ }^{91}$. Zaznaczył swą obecność także w obszarze pedagogiki porównawczej ${ }^{92}$. Jego dotychczasowy dorobek naukowy obejmuje ponad 130 pozycji, w tym kilku prac zwartych samodzielnych oraz napisanych wspólnie z prof. $K$. Trzebiatowskim.

Pasją dr J. Żerko jest również działalność organizacyjna. Kierownicze funkcje pełnił jeszcze przed podjęciem pracy w UG, m.in. w Komendzie Koszalińskiej Chorągwi Harcerstwa, w Szkole Podstawowej nr 67 w Gdańsku (zastępca dyrektora). W okresie pracy w Uniwersytecie Gdańskim był m.in.: zastępcą dyrektora Instytutu Pedagogiki oraz kierownikiem Studiów Zaocznych Wydziału Nauk Społecznych. Przez dwie kadencja pełnił też funkcję prodziekana Wydziału Nauk Społecznych UG ${ }^{93}$.

Po przejściu na emeryturę w 2007 r. współpracuje z Zakładem w ramach godzin zleconych, kierując seminarium magisterskim.

W latach 1985-1989 etatowym pracownikiem Zakładu Historii Nauki, Oświaty i Wychowania był tragicznie zmarły dr Henryk Rostek (1952-1989). Absolwent Technikum Przemysłowo-Pedagogicznego w Gdańsku, w roku 1973 rozpoczął pracę jako wychowawca w internacie Zespołu Szkół Budowlanych w Gdańsku. Po kilku tygodniach zyskał jednak możność podjęcia studiów stacjonarnych na kierunku pedagogiki szkolnej w Uniwersytecie Gdańskim. Okres studiów stał się dla H. Rostka etapem intensywnego rozwoju naukowego. Nie tylko aktywnie uczestniczył w wykładach i seminariach, ale działał też w Studenckim Kole Naukowym Pedagogów. Brał udział w obozach naukowych oraz prezentował rezultaty badań na forum studenckich konferencji naukowych ${ }^{94}$. Po ukończeniu studiów podjął pracę w internacie jednego z ówczesnych zespołów szkół w Gdańsku. Nie zrezygnował jednak z aktywności naukowej. Uczestnicząc w seminariach kadry pro-

\footnotetext{
${ }^{88}$ Dzieci, młodzież, dorośli w systemie edukacji (wybrane konteksty), w: Studia i badania naukowe "Ateneum - Szkoły Wyższej", t. II. Pedagogika, red. J. Żerko, Gdańsk 2008. Por. także: Szlakami przeszlości i czasów wspótczesnych, pod red. K. Puchowskiego i J. Żerko, Gdańsk 1996.

${ }^{89}$ J. Żerko, Ruch młodzieżowy w 40-leciu PRL w województwie gdańskim, w: Studia z dziejów ruchu młodzieżowego. Zwiqzek Mtodzieży Polskiej woj. Gdańskim, t. 3, Gdańsk 1985; idem, Stan badań nad dziejami ruchu młodzieżowego na ziemi gdańskiej, w: Studia z dziejów ruchu młodzieżowego (Rozprawy, materiały, przyczynki), t. 1, Gdańsk 1984.

${ }^{90} \mathrm{~J}$. Żerko, Wychowanie morskie w procesie dydaktyczno-wychowawczej szkoły podstawowej, „Nautologia" 1981, nr 4, s. 25-32; idem, Problematyka wychowania morskiego w Hufcu Morskim w Gdyni w latach 1928-1946, w: Studia z dziejów ruchu młodzieżowego (Rozprawy, materiały i przyczynki), t. !, Gdańsk 1984, s. $68-84$.

${ }^{91} \mathrm{~J}$. Żerko, „Resocjalizacja nieletnich przestępców w zakładach poprawczych w Polsce. Raport w temacie CPBP 08,3", Gdańsk 1990 (mpis); idem, System resocjalizacji nieletnich w opinii byłych wychowanków zakładów poprawczych, w: Patologia spoleczna wśród dzieci i młodzieży, pod red. Z. Płoszyńskiego, T. Wróblewskiej, WSP Słupsk 1993, t. II.

${ }^{92}$ Ksztalcenie nauczycieli $w$ wybranych krajach świata, red. L. Burzyńska, H. Hovenberg, W. J. Wojtowicz, J. Żerko, Gdańsk - Linköping 1998.

${ }^{93}$ Funkcje kierownicze pełni też w szkołach prywatnych, w tym m.in. w Ateneum - Szkole Wyższej, w której od 2004 r. jest dziekanem Wydziału Studiów Edukacyjnych.

${ }^{94}$ Por. J., Żerko, Dr Henryk Rostek (1952-1989), ,Zeszyty Naukowe UG, Rozprawy i monografie. Pedagogika, Historia wychowania" 1991, nr 19, s. 204-206.
} 
fesorskiej Instytutu Pedagogiki (początkowo prof. Romany Miller, a następnie prof. L. Mokrzeckiego) przygotował pierwsze publikacje, które ukazały się m.in. w „Problemach Opiekuńczo-Wychowawczych”, „Wsi Współczesnej” i innych periodykach. Przedmiotem jego wczesnych zainteresowań badawczych były zagadnienia związane $\mathrm{z}$ rozwojem kultury i edukacji w środowisku wiejskim.

Od 1983 roku H. Rostek podjął pracę - w wymiarze 1/2 etatu - w Zakładzie Historii Nauki, Oświaty i Wychowania. Od roku 1985 był już etatowym pracownikiem Zakładu, zatrudnionym na stanowisku starszego asystenta. W tym czasie zintensyfikował wysiłki mające na celu własny awans naukowy. Pod kierunkiem doc. dr hab. Ryszarda Borowicza z Uniwersytetu Mikołaja Kopernika w Toruniu przygotował rozprawę doktorską pt. „Problemy egzystencjalne młodzieży. Studium teoretyczno-poznawcze",95. W tym okresie wiele publikował. Interesowały go sprawy młodzieży, głównie natury egzystencjalnej ${ }^{96}$, ale dostrzegał też problemy uczniów mieszkających w internacie ${ }^{97}$. W tym kontekście podejmował badania poświęcone działalności ówczesnych organizacji młodzieżowych ${ }^{98}$. Jako znakomity znawca zagadnień związanych $\mathrm{z}$ pracą $\mathrm{w}$ internacie wiele uwagi poświęcał przygotowaniu kadr pedagogicznych dla tych placówek ${ }^{99}$. Ogólem w ciągu swego krótkiego życia H. Rostek opublikował 36 artykułów i recenzji.

Trwałym elementem dorobku dr. H. Rostka stała się ekspozycja typu muzealnego w Instytucie Pedagogiki, którą stworzył wspólnie z dr. Jerzym Szewsem i prof. L. Mokrzeckim. W rezultacie Instytut Pedagogiki UG, jako jeden z nielicznych w Polsce, może poszczycić się „,salą tradycji”, w której zgromadzono eksponaty obrazujące zarówno rozwój pedagogiki w obrębie WSP i UG, jak i pamiątki ilustrujące rozwój oświaty i wychowania na Pomorzu Gdańskim w XIX w XX wieku ${ }^{100}$.

Przez kilkanaście lat pracownikiem Zakładu była dr Janina Siwoszko (1946-2008). Absolwentka Liceum Pedagogicznego w Lęborku, ukończyła studia historyczne w Wyższej Szkole Pedagogicznej w Opolu (1970 r.). Jako magister historii początkowo pracowała w lokalnej administracji oświatowej Lęborku, a następnie w Gdańsku, pełniąc w niej funkcje kierownicze. W Gdańsku też, w połowie lat 70. podjęła pracę w Oddziale Doskonalenia Nauczycieli, a następnie w Centrum Edukacji Teatralnej Dzieci i Młodzieży. W latach 1976-1984, w ramach zaocznego studium doktoranckiego, funkcjonującego

\footnotetext{
${ }^{95}$ Publiczna obrona odbyła się w dniu 2 lipca 1986 r., w Instytucie Pedagogiki UG.

${ }^{96}$ H. Rostek, Mtodzież a problemy egzystencji, „Kwartalnik Pedagogiczny” 1982, nr 3-4; idem, Egzystencjalne problemy mtodzieży, „Polska Młodzież” 1987, nr 3-4; idem, Człowiek w poszukiwaniu sensy życia, „Człowiek i Światopogląd" 1987, nr 6.

${ }^{97}$ H. Rostek, Wychowanie przez prace $w$ internacie, „Problemy Opiekuńczo-Wychowawcze" 1980, nr 4; idem, Uwagi o wychowaniu internatowym, „Nauczyciel i Wychowanie” 1983, nr 1-2; idem, Kadry dla internatów, „Oświata i Wychowanie" 1982, nr 1 i inne.

${ }^{98}$ H. Rostek, Wychowawcza rola organizacji młodzieżowych, „Nauczyciel i Wychowanie" 1986, nr 5-6; idem, Funkcje wychowawcze organizacji młodzieżowych w szkole, w: „Kalendarz Nauczycielski” 1987; idem, Samorzqd uczniowski $i$ młodzieżowe organizacje w społeczności szkoły zawodowej, „Szkoła Zawodowa" 1987, nr 7-8.

${ }^{99}$ H. Rostek, Problemy kadrowe burs $i$ internatów, „Nauczyciel i Wychowanie" 1988, nr 1; idem, Kadry dla internatów, „Oświata i Wychowanie” 1982, nr 1.

${ }^{100}$ Sala tradycji Instytutu Pedagogiki „Zyje” nadal dzięki staraniom innych pracowników Zakładu, a przede wszystkim prof. L. Mokrzeckiego, dr. Tomasza Maliszewskiego, Mariusza Brodnickiego i innych.
} 
przy Instytucie Kształcenia Nauczycieli w Warszawie, przygotowywała rozprawę doktorską na temat: „Kadra kierownicza oświaty i jej sprawność w zarządzaniu szkolnictwem (na przykładzie Makroregionu Północnego)". Promotorem rozprawy, której obrona odbyła się w 1984 r., był prof. dr hab. Tadeusz Wiloch ${ }^{101} .1$ października 1988 r. J. Siwoszko została zatrudniona na stanowisku adiunkta w Zakładzie Historii Nauki, Oświaty i Wychowania. Od 1 października 1997 r. zajmowała stanowisko starszego wykładowcy w tymże Zakładzie. Z dniem 30 września 2005 r. przeszła na emeryturę. Zmarła niespodziewanie w roku 2008, po krótkiej, ciężkiej chorobie.

Zainteresowania naukowe J. Siwoszko początkowo koncentrowały się wokół problemów organizacji i zarządzania oświatą. Zajmowała ją szczególnie problematyka sprawności zarządzania placówkami oświatowymi i roli pracowników administracji oświatowej w tym procesie ${ }^{102}$. Po przejściu do UG rozszerzyła zakres badań o zagadnienia dotyczące kształcenia kadr pedagogicznych i adaptacji młodych nauczycieli w środowisku szkolnym. Najwięcej uwagi poświęcała w tym okresie problematyce organizacji szkolnictwa w Polsce oraz w innych krajach Europy ${ }^{103}$. Studia porównawcze, które mocno ją w tym okresie angażowały, zaowocowały wyjazdem naukowym do Wielkiej Brytanii (w ramach wymiany międzynarodowej TEMPUS - ADEPT) ${ }^{104}$. Podejmowała też zagadnienia związane ze szkolnictwem prywatnym ${ }^{105}$ oraz rolą i miejscem szkoły w nowoczesnym społeczeństwie obywatelskim $^{106}$.

J. Siwoszko, autorka kilkunastu artykułów i raportów, była nie tylko badaczem problematyki oświatowej, ujmowanej na tle porównawczym, ale prowadziła też seminarium magisterskie, na którym kilkudziesięciu studentów pedagogiki napisało prace magisterskie.

Przez kilka lat z Zakładem Historii Oświaty i Wychowania dość ściśle współpracował doc. dr hab. Wiktor Frąckowiak (1932-1987), na co dzień etatowy pracownik Wyższej Szkoły Pedagogicznej w Bydgoszczy, a następnie Akademii Wychowania Fizycznego w Gdańsku. Urodził się w Poznaniu, w rodzinie powstańca wielkopolskiego, w której odebrał bardzo głębokie wychowanie patriotyczne. Absolwent Liceum Pedagogicznego w Poznaniu, zdobywał doświadczenie pedagogiczne początkowo jako wychowawca domu dziecka, a następnie nauczyciel szkoły zawodowej i kierownik szkoły podstawowej. Systematycznie uzupełniał swe wykształcenie, początkowo w Zaocznym Studium Nauczycielskim w Poznaniu, następnie w Wyższej Szkole Pedagogicznej w Gdańsku. Tu

\footnotetext{
${ }^{101}$ Akta osobowe J. Siwoszko. Archiwum Uniwersytetu Gdańskiego.

${ }^{102} \mathrm{~J}$. Siwoszko, Kadra kierownicza oświaty i jej sprawność w zarzqdzaniu szkolnictwem na przykładzie Makroregionu Pólnocnego, w: Rozprawy doktorskie z organizacji i zarzq̨dzania oświatą (1977-1988). ODN Warszawa 1999, s. 167-177.

${ }^{103}$ J. Siwoszko, System zarzqdzania oświata $w$ Polsce $i w$ innych krajach Europy. Studium porównawcze, w: Sprawozdania Gdańskiego Towarzystwa Naukowego 1994, t. 21, red. K. Kozłowski, s. 111-119.

${ }^{104} \mathrm{~J}$. Siwoszko, Angielski system ksztatcenia nauczycieli na tle systemów ksztatcenia nauczycieli $w$ wybranych krajach, Gdańsk 19993 (raport).

${ }^{105} \mathrm{~J}$. Siwoszko, „Z badań nad gdańskim szkolnictwem prywatnym" - referat wygłoszony na Międzynarodowej Konferencji Naukowej pt. Oświata w okresie przemian ustrojowych w Polsce, zorganizowanej w ramach szwedzko-polskiego projektu „S(z)koldem”.

${ }^{106} \mathrm{~J}$. Siwoszko, Szkoła w spoteczeństwie obywatelskim, w: Wychowanie a spoteczeństwo obywatelskie, pod red. J. Żebrowskiego, Gdańsk 1994, s. 121-125.
} 
też uzyskał dyplom magistra pedagogiki na podstawie pracy pt. „Dzieje Gimnazjum Polskiego w Kwidzynie", napisanej na seminarium kierowanym przez prof. K. Kubika.

Po roku pracy na stanowisku podinspektora szkolnego na terenie Wielkopolski został zatrudniony w charakterze nauczyciela w Studium Nauczycielskim Wychowania Fizycznego w Gdańsku ${ }^{107}$. W tym czasie na seminarium doktorskim kierowanym przez prof. K. Kubika przygotowywał rozprawę doktorską zatytułowaną „Podręczniki do nauczania języka polskiego na Pomorzu w latach 1862-1918", obronioną w WSP w Gdańsku w 1973 roku. Równolegle prowadził zajęcia z zakresu historii wychowania w Katedrze Historii Oświaty i Wychowania. W dalszych latach konsekwentnie rozwijał swe zainteresowania badawcze, skupione na problematyce edukacji narodowej i patriotycznej dzieci polskich na Pomorzu Nadwiślańskim w okresie zaboru pruskiego. Potwierdzeniem tego była problematyka podjęta w pracy habilitacyjnej, zatytułowanej „Pedagogiczne aspekty polskiego czasopiśmiennictwa dla dzieci młodzieży na Pomorzu Nadwiślańskim i na Kujawach Zachodnich w okresie działalności rządów Bismarcka 1862-1890". Stopień doktora habilitowanego W. Frąckowiak uzyskał na Wydziale Humanistycznym Uniwersytetu Gdańskiego w roku 1980.

Zatrudniony na stanowisku docenta w WSP w Bydgoszczy ${ }^{108}$, W. Frąckowiak kierował seminarium magisterskim i doktorskim. Pod jego kierunkiem pracę doktorską napisał ówczesny magister Krzysztof Jakubiak. W latach 80. XX w. W. Frąckowiak etatowo związał się ponownie z Wyższą Szkołą Wychowania Fizycznego w Gdańsku, gdzie prowadził zajęcia z zakresu metodologii badań naukowych. Od 1983 r. równolegle pracował na etacie docenta w Instytucie Pedagogiki UG, gdzie prowadził wykłady $\mathbf{z}$ historii wychowania oraz kierował seminarium magisterskim. W całym okresie aktywnej działalności naukowej doc. W. Frąckowiak podejmował badania skupione wokół problematyki oświaty polskiej $\mathrm{w}$ zaborze pruskim. Wiele uwagi poświęcił zwłaszcza roli czasopism polskich w procesie edukacji elementarnej dzieci polskich ${ }^{109}$. Żywo interesowała go też patriotyczna i wychowawcza działalność Towarzystwa Gimnastycznego Sokól" na terenie Pomorza Gdańskiego ${ }^{110}$. Ogółem W. Frąckowiak napisał 4 książki i opublikował kilkadziesiąt artykułów ${ }^{111}$.

\footnotetext{
${ }^{107}$ Przekształconym w roku 1969 w Wyższą Szkołę Wychowania Fizycznego w Gdańsku.

${ }^{108}$ Z WSP w Bydgoszczy związał się w roku 1973, po likwidacji Zakładu Dydaktyki Nauczania Początkowego w WSWF w Gdańsku. W uczelni bydgoskiej pelnił funkcje kierownika Zakładu Teorii i Historii Wychowania.

${ }^{109}$ Wydawnictwa $z$ zakresu elementarnej nauki języka polskiego na Pomorzu Gdańskim $w$ latach 1840-1920, Gdańsk 1977; idem: Pedagogiczne aspekty polskiego czasopiśmiennictwa dla dzieci i młodzieży na Pomorzu Nadwiślańskim i Kujawach Zachodnich w okresie rządów Bismarcka (1862-1890), Bydgoszcz 1979; idem, Pedagogiczne tendencje pomorskiej $i$ kujawskiej prasy polskiej dla dzieci i młodzieży w latach 1891-1920, Bydgoszcz 1981; idem, Bibliografia polskiego czasopiśmiennictwa dla dzieci i młodzieży na Pomorzu pod zaborem pruskim (1865-1920), „Rocznik Gdański” 1976, T. XXXVI, z. 1, s. 189-194.

${ }^{110}$ Przygotowaną przez W. Frąckowiaka interesującą książkę na ten temat piszącemu te słowa udało się odnaleźć $\mathrm{w}$ jednym $\mathrm{z}$ wydawnictw uczelnianych i wydać drukiem (ze środków syna - Piotra Wiktora Frąckowiaka), dopiero jedenaście lat po śmierci autora. Por.: W. Frąckowiak, Dzieje Towarzystw Gimnastycznych "Sokót" na Pomorzu Nadwiślańskim w latach 1886-1919, Gdańsk 1998.

${ }^{111}$ Bibliografia prac docenta dr hab. Wiktora Frąckowiaka, „ZNWH, Pedagogika, Historia Wychowania" 1988 , nr 18, s. $153-157$.
} 
Osobne miejsce w historii Zakładu zajmują nauczyciele akademiccy, którzy na co dzień byli związani etatowo $\mathrm{z}$ innym szkołami wyższymi w Gdańsku. Zatrudnieni na części etatu prowadzili zajęcia dydaktyczne $\mathrm{z}$ historii wychowania oraz uczestniczyli w życiu naukowym zakładu, przyczyniając się do jego dalszego rozwoju. Wspomnieć należy w tym kontekście o dwóch doktorantach prof. K. Kubika: dr. Walentym Aleksandrowiczu oraz dr. Zdzislawie Piątku.

Przez kilka lat z Zakładem twórczo współpracował ówczesny docent Karol Toeplitz.

\section{Kadra Zakładu w pierwszych latach XXI wieku}

W latach 80. XX w. w Zakładzie Historii Nauki, Oświaty i Wychowania pracę podjęli przedstawiciele kolejnego pokolenia badaczy dziejów oświaty ${ }^{112}$. Od 1 października 1980 roku na stanowisku asystenta zatrudniono mgr. Witolda Wierzbickiego ${ }^{113}$, od 1 stycznia 1981 roku mgr. Romualda Grzybowskiego ${ }^{114}$. W związku z restrukturyzacją Uczelni, w pierwszej połowie lat 80 . XX w. do grona pracowników Zakładu dołączył mgr Jerzy Szmytka, pedagog związany dotąd z Zakładem Technicznych Środków Nauczania ${ }^{115}$.

1 października 1983 pracę w Zakładzie podjął roku mgr Kazimierz Puchowski ${ }^{116}$, 1 października 1986 r. na stanowisku adiunkta zatrudniona została mgr Lidia Burzyńska-Wentlad ${ }^{117}$, zaś od 1 września 1987 roku członkiem Zakładu został mgr Jacek

\footnotetext{
${ }^{112} \mathrm{~W}$ tej części opracowania ograniczam się do przedstawienia podstawowych danych o rozwoju naukowym pracowników Zakładu, dla których Uniwersytet Gdański jest obecnie podstawowym miejscem zatrudnienia.

${ }^{113}$ Po uzyskaniu stopnia doktora nauk humanistycznych (w czerwcu 1987 r.), z dniem 30 września 1988 r. przeszedł do pracy w szkolnictwie średnim w Gdańsku.

${ }^{114}$ Stopień doktora uzyskał w dniu 13 marca 1987 r. na Wydziale Humanistycznym UG, na podstawie pracy pt. „Problematyka kształcenia nauczycieli na poziomie średnim w województwie gdańskim w latach 1945-1975", (Promotor: prof. Lech Mokrzecki). Z dniem 30 września 1988 r. zrezygnował z pracy w UG. Po dwuletnim okresie działalności w sektorze prywatnym, 15 września 1990 r. został zatrudniony w Akademii Wychowania Fizycznego w Gdańsku, w Zakładzie Pedagogiki. W tym czasie współpracował z Zakładem Historii Nauki, Oświaty i Wychowania na niwie dydaktycznej i naukowej. W roku 2000 habilitował się na Wydziale Nauk Społecznych UG, na podstawie dorobku naukowego i pracy pt. Wyższe szkoly pedagogiczne w Polsce w latach 1946-1956 (Gdańsk 2000). W latach 2002-2005 kierował Katedrą Nauk Humanistycznych AWFiS w Gdańsku. 1 października 2005 r. przeszedł do Uniwersytetu Gdańskiego, obejmując kierownictwo Zakładu Historii Nauki, Oświaty i Wychowania. W wyniku wyborów, 1 września 2008 r. objął stanowisko dyrektora Instytutu Pedagogiki UG.

${ }^{115}$ Został zatrudniony na stanowisku wykładowcy, prowadził zajęcia z przedmiotu „pedagogika” na studiach nauczycielskich. Od 1 października 2006 r. na emeryturze.

${ }^{116}$ Stopień doktora nauk humanistycznych uzyskał w roku 1990 na Wydziale Humanistycznym UG, na podstawie pracy pt. „Edukacja historyczna w jezuickich kolegiach Rzeczypospolitej (1765-1773)”, (Promotor: prof. Lech Mokrzecki). W roku 2008 habilitował się na Wydziale Nauk Społecznych UG, na podstawie dorobku i pracy pt. „Jezuickie kolegia szlacheckie Rzeczypospolitej Obojga Narodów. Studium z dziejów edukacji elit" (Gdańsk 2007). W latach 1993-1999 pełnił funkcję prodziekana Wydziału Nauk Społecznych UG.

${ }^{117}$ Stopień doktora nauk humanistycznych uzyskała na Wydziale Nauk Spolecznych UG w dniu 11 maja 1995 r., na podstawie dysertacji pt. "Strajki szkolne w Prusach Zachodnich w latach 1906-1907 i stosunek do nich społeczeństwa polskiego, (Promotor: prof. J. Borzyszkowski).
} 
Taraszkiewicz $^{118}$. Przez kilka lat, z przerwami na urlop macierzyński, asystentką w Zakładzie była mgr Małgorzata Lachowicz-Strugała ${ }^{19}$. Natomiast 1 października 1990 r. etatowym pracownikiem Zakładu został mgr Tomasz Maliszewski ${ }^{120}$.

Tabela 3. Pracownicy Zakładu Historii Nauki, Oświaty i Wychowania w roku akad. 2007/2008

\begin{tabular}{|c|l|l|l|}
\hline Lp. & \multicolumn{1}{|c|}{ Imię i nazwisko } & \multicolumn{1}{|c|}{ Tytuł, stopień naukowy } & \multicolumn{1}{c|}{ W Zakładzie od: } \\
\hline 1 & $\begin{array}{l}\text { Romuald Grzybowski } \\
\text { (kier. Zakładu) }\end{array}$ & prof. UG, dr hab. & 1.01 .1981 - 30. 09. 1988; 1. 10. 2005 \\
\hline 2 & Kazimierz Puchowski & prof. UG, dr hab. & 1.10 .1983 r. \\
\hline 3 & K. Jakubiak & prof. UG, dr hab. & 1.10 .2007 r. \\
\hline 4 & Lidia Burzyńska-Wentland & dr adiunkt & 1.10 .1986 r. \\
\hline 5 & Jacek Taraszkiewicz & dr adiunkt & 1.09 .1987 r. \\
\hline 6 & Tomasz Maliszewski & dr adiunkt & 1.10 .1990 r. \\
\hline 7 & Mariusz Brodnicki & dr adiunkt & 1.10 .2004 r \\
\hline 8 & Anna Paszkowska & mgr (asystent) & 1.11 .2006 r. \\
\hline 9 & Andrzej Kołakowski & mgr (asystent) & 12.02 .2007 r. \\
\hline 10 & Elżbieta Gorllof & dr (adiunkt) & 1.10 .2007 r. \\
\hline 11 & Zofia Anikej & mgr (asystent) & 1.11 .2005 r. - do 30. 06. 2008 r. (zła) \\
\hline 12 & Lech Mokrzecki & prof. dr hab. (godz. zlec.) & \\
\hline 13 & Józef Żerko & dr (godz. zlec.) & \\
\hline & & &
\end{tabular}

Najmłodsze stażem pokolenie badaczy weszło w skład Zakładu już w XXI w. Są to: mgr Mariusz Brodnicki (od 1 października 2004 r.), dr Andrzej Kołakowski ( od 12. 02. 2006 r.) ${ }^{121}$, dr Elżbieta Gorloff (od 1 października 2007) ${ }^{122}$ oraz mgr Anna Paszkowska (od 1 listopada 2006 r.). W latach 2005-2008 na stanowisku asystenta była zatrudniona mgr Zofia Anikej ${ }^{123}$. Znaczącym wzmocnieniem kadrowym Zakładu okazało się pozyskanie od 1 października 2007 roku prof. UG, dr hab. Krzysztofa Jakubiaka z Uniwersy-

\footnotetext{
${ }^{118}$ W roku 1995, na Wydziale Nauk Społecznych UG uzyskał na podstawie pracy pt. „Nauczanie historii w szkolnictwie pijarskim w okresie staropolskim, [promotor: prof. L. Mokrzecki] - stopień doktora. W latach 1999-2002 prodziekan Wydziału Nauk Społecznych UG, zaś w okresie 2002-2008 prorektor do spraw studenckich Uniwersytetu Gdańskiego.

${ }^{119}$ Odeszła z Zakładu z dniem 30 września 2005 r.

${ }^{120}$ Stopień doktora nauk humanistycznych uzyskał na Wydziale Nauk Spolecznych w dniu 19 maja 1999 r., na podstawie dysertacji pt. Kierunki działalności uniwersytetów ludowych w Szwecji (1868-1996) (Promotor: prof. Lech Mokrzecki).

${ }^{121}$ Stopień doktora nauk humanistycznych uzyskał na Wydziale Nauk Społecznych UG, w dniu 6 grudnia 2006 r. na podstawie pracy pt. „System instytucjonalnej opieki całkowitej nad dzieckiem w Polsce w latach 1945-1956 i jego realizacja w domach dziecka w województwie gdańskim” (Promotor: prof. UG, Romuald Grzybowski).

${ }^{122}$ Stopień doktora uzyskała na Wydziale nauk Społecznych UG, w dniu 1 lutego 2007 r., na podstawie pracy pt. „Szkolnictwo w Lęborku w latach 1945-1989” (Promotor: prof. UG, Romuald Grzybowski).

${ }^{123}$ Po wyjeździe do Irlandii zrezygnowała z pracy naukowej w Zakładzie.
} 
tetu Kazimierza Wielkiego z Bydgoszczy ${ }^{124}$. Ponadto w skład Zakładu wchodzi prof. dr hab. Marcin Tomczak - prorektor Akademii Muzycznej w Gdańsku, dyrygent chóru Uniwersytetu Gdańskiego.

Mimo pięćdziesięciu lat istnienia Zakład Historii Nauki, Oświaty i Wychowania nie zwalnia tempa działalności naukowej i dydaktycznej, choć dokonująca się w nim wymiana kadrowa pociąga za sobą nieuchronne zmiany w zakresie problematyki badawczej. Wynikają też one z konieczności dostosowania się kadry naukowo-dydaktycznej do zmieniających się uwarunkowań rozwoju nauki i szkolnictwa wyższego w Polsce. Niezmienne pozostają zasady pracy naukowej, w tym zwłaszcza wysokie wymagania wobec własnych prac badawczych, zaangażowanie w proces kształcenia oraz życzliwość wobec studentów. Corocznie pracownicy Zakładu publikują kolejne książki i artykuły naukowe, podejmują nowe i kontynuują badania rozpoczęte jeszcze przez naszych znakomitych poprzedników - mistrzów i wychowawców. Wśród badaczy młodszego pokolenia żywa jest pamięć o dorobku zarówno prof. K. Kubika, jak i prof. K. Trzebiatowskiego. Na co dzień w życiu Zakładu aktywnie uczestniczy prof. L. Mokrzecki oraz dr J. Żerko. Cementuje to zespół i tworzy znakomite warunki do prowadzenie dalszych, intensywnych dociekań naukowych.

\section{Romuald Grzybowski}

\section{Fiftieth Anniversary of History of Education in Gdańsk}

In 2009, the Faculty of the History of Science, Learning and Education, operating within the structures of the Institute of Pedagogics at Gdańsk University, will celebrate 50th anniversary of its existence. The beginnings of the Faculty and the first years of its operation are inseparably connected with the Higher School of Pedagogics in Gdańsk, in which, in 1958 students were offered courses in pedagogics. Following these developments, a proper organizational framework was established, which was supposed to promote the development of such studies. One of the elements was the Department of History of Learning and Education, renamed - at the close of the 1960 s - the Faculty of the History of Learning and Education. Since 1983 it is the Faculty of the History of Science, Learning and Education.

The founder and first director of the Department, and later of the Faculty was Professor Kazimierz Kubik. Following him, it was Professor Klemens Trzebiatowski who headed the Faculty for three years. Professor Lech Mokrzecki was the subsequent director for over twenty years. Since 2005, Professor Romuald Grzybowski from Gdańsk University has been the head of the Faculty.

\footnotetext{
${ }^{124}$ Stopień doktora nauk humanistycznych uzyskał na Wydziale Humanistycznym UG w roku 1986, na podstawie dysertacji pt. „Udział społeczno-pedagogicznych i kulturalnych wydawnictw sanacyjnych w kształtowaniu doktryny wychowania państwowego w Polsce", przygotowanej pod kierunkiem doc. dr hab. Wiktora Frąckowiaka. W roku 1997 habilitował się na Uniwersytecie Adama Mickiewicza w Poznaniu, na podstawie dorobku naukowego i pracy pt. Wspótdziałanie rodziny $i$ szkoły w pedagogice II Rzeczpospolitej (Bydgoszcz 1997).
} 
Since the foundation of the Faculty, its employees have been conducting intensive scholarly research, originally limited to local or regional studies, and later comprising all Poland. Numerous book publications, papers and lectures delivered at scholarly conferences, form a material confirmation of intense scholarly activity by research and teaching staff of the Faculty. The scholarly conferences organized or co-organized by individual Faculty employees must be evaluated similarly. Another confirmation of the energy of the Faculty is participation of its employees in the process of education of the young ranks of scholars.

The completion of ambitious tasks was possible due to such factors as stability of scholarly staff combined with their systematic replacement, good relationships between the Faculty's employees, and, first of all, creative personality of successive directors of the Faculty. Owing to this creativity, the Faculty has not only survived, but develops intensively in all spheres of scholarly and didactic activity. 